Vegetation and Channel Morphology Responses to Ordinary High Water Discharge Events in Arid West Stream Channels

Robert Lichvar, David Cate, Corinna Photos,

Lindsey Dixon, Bruce Allen, and Joel Byersdorfer

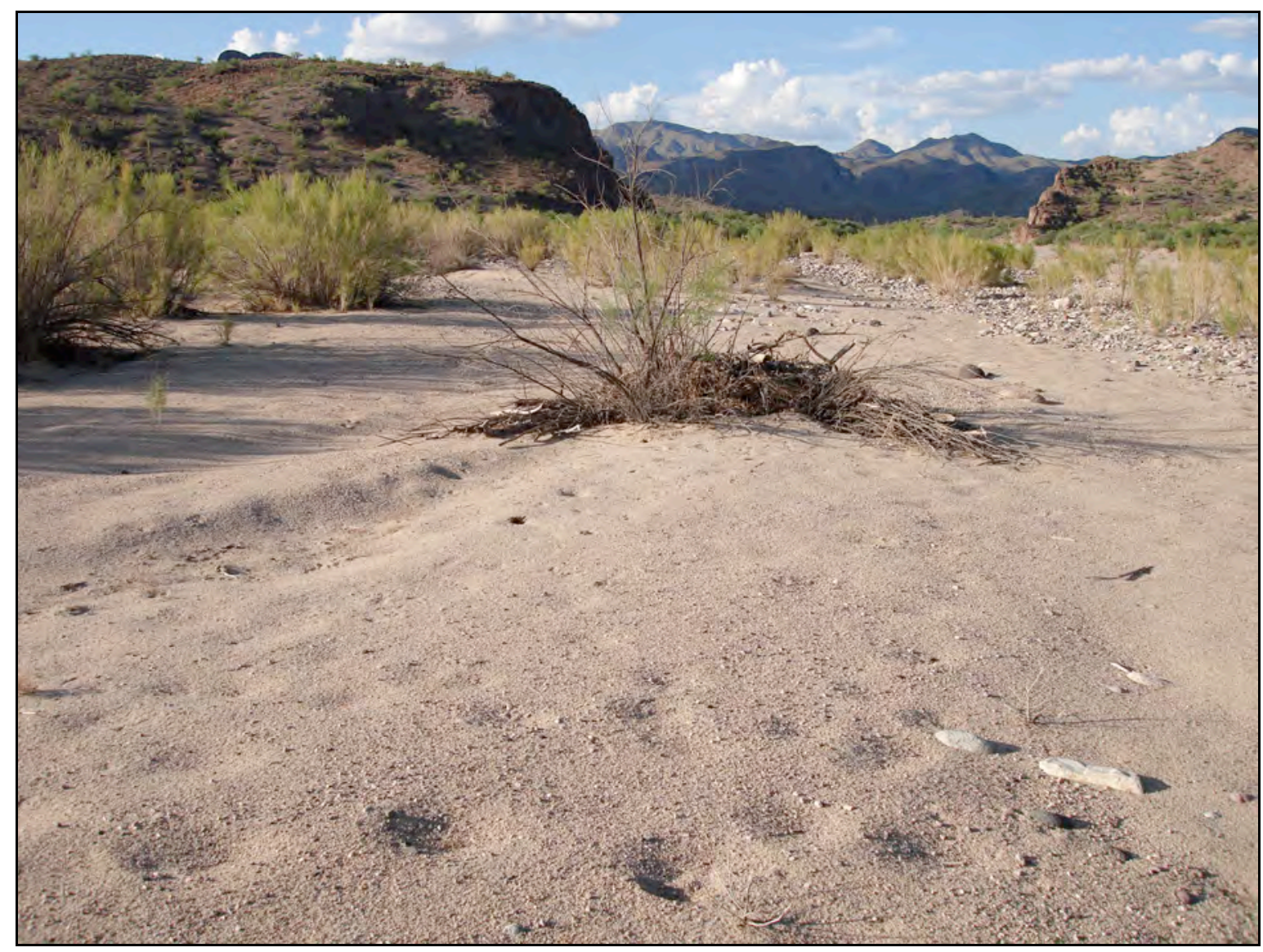




\section{Vegetation and Channel Morphology Responses to Ordinary High Water Discharge Events in Arid West Stream Channels}

Robert Lichvar, David Cate, Corinna Photos, Lindsey Dixon, Bruce Allen, and Joel Byersdorfer

Cold Regions Research and Engineering Laboratory

U.S. Army Engineer Research and Development Center 72 Lyme Road

Hanover, NH 03755-1290

Approved for public release; distribution is unlimited.

Prepared for Headquarters, U.S. Army Corps of Engineers

Washington, DC 20314-1000 


\begin{abstract}
Waters of the United States" (WoUS) are regulated by the U.S. Army Corps of Engineers under Section 404 of the Clean Water Act (33 U.S.C. 1344). The Corps lateral jurisdictional extent in Arid West stream channels is the upper level of the ordinary high water (OHW). The channel shape, fluvial textures, and vegetation patterns of these arid stream channels are heavily influenced by short-term, high-intensity or "flashy" events, which create distinctive physical features and vegetation responses. To determine vegetation and channel morphology responses, sequential aerial photos and stream gauge data for eight ephemeral and intermittent stream channels in the Arid West were analyzed. The observed patterns associated with various discharge event levels are consistent with the Corps OHW delineation manual. The use of remote sensing resources provides another critical component for aiding in the delineation of the extent of the OHW in Arid West stream channels.
\end{abstract}




\section{Contents}

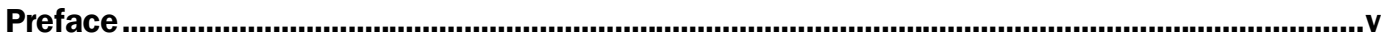

Unit Conversion Factors......................................................................................................... vi

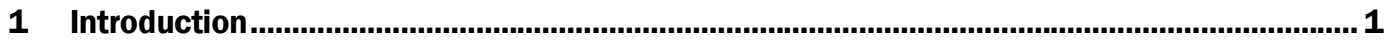

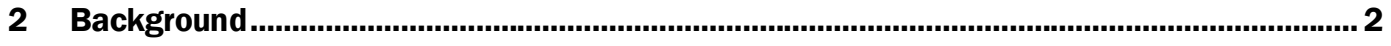

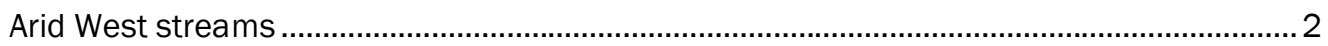

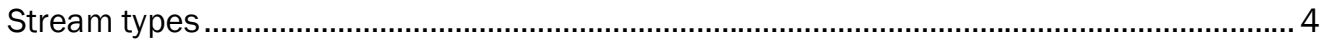

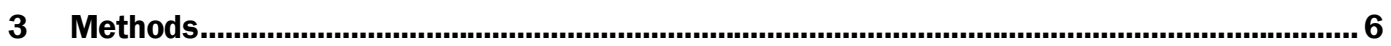

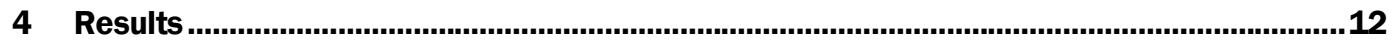

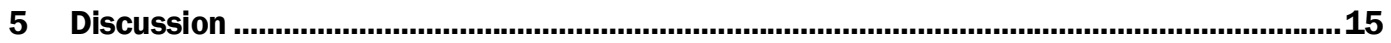

Channel morphology and vegetation changes ..............................................................15

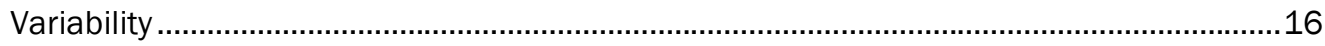

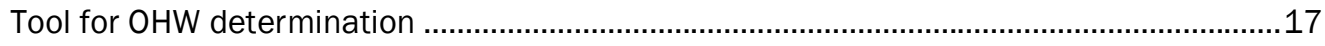

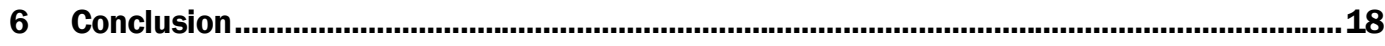

References.................................................................................................................................19

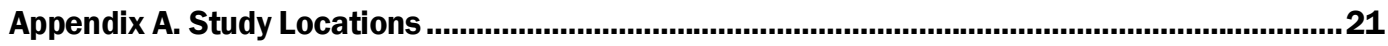

Appendix B. Aerial Imagery and Discharge Events...........................................................22

Appendix C. Aerial Photos and Channel Morphological and Vegetation Delineation................23

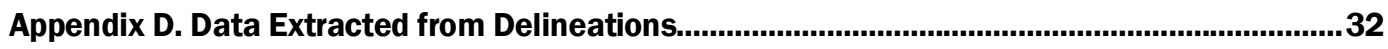

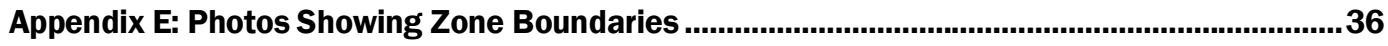

Report Documentation Page ........................................................................................................... 41 


\section{Figures and Tables}

\section{Figures}

Figure 1. Typical cross section depicting hydrogeomorphic floodplain units for typical streams 3

Figure 2. The Arid West region as defined by Land Resource Regions B, C, and D ........................... 7

Figure 3. Site stream locations overlaid with land resource regions ................................................... 8

Figure 4. Chinle Creek near Mexican Water, AZ ……………..............................................................

Figure 5. Vegetation categories at two sites .................................................................................11

Figure 6. Mean changes in channel morphology zones .................................................................12

Figure 7. Mean changes in vegetation for all sites ..........................................................................13

\section{Tables}

Table 1. Natural controls on fluvial processes .4

Table 2. Percent change in area between photo pairs for channel morphology zones and vegetation for all sites and for those with flood return intervals of fewer than or greater than 5 years 


\section{Preface}

This report was prepared by Robert W. Lichvar, David Cate, Corinna Photos, Lindsey Dixon, Bruce Allen, and Joel Byersdorfer, Remote Sensing/GIS and Water Resources Branch, Cold Regions Research and Engineering Laboratory (CRREL), U.S. Army Engineer Research and Development Center (ERDC), Hanover, NH.

The authors thank Michael Ericsson for collecting field data and Shawn McColley for suggesting analytical methods. Funding for this effort was provided under the WRAP Regulatory Program, Headquarters, U.S. Army Corps of Engineers.

The report was prepared under the general supervision of Timothy Pangburn, Chief, RS/GIS and Water Resources Branch, CRREL; Dr. Justin B. Berman, Chief, Research and Engineering Division, CRREL; Dr. Lance Hansen, Deputy Director, CRREL; and Dr. Robert E. Davis, Director, CRREL.

The Commander and Executive Director of ERDC is COL Gary E. Johnston. The Director is Dr. James R. Houston. 


\section{Unit Conversion Factors}

\begin{tabular}{|l|c|l|}
\hline Multiply & By & To Obtain \\
\hline cubic feet & 0.02831685 & cubic meters \\
\hline feet & 0.3048 & meters \\
\hline miles (U.S. statute) & $1,609.347$ & meters \\
\hline square feet & 0.09290304 & square meters \\
\hline square miles & $2.589998 \mathrm{E}+06$ & square meters \\
\hline
\end{tabular}




\section{Introduction}

Under the U.S. Army Corps of Engineers (USACE) and the U.S. Environmental Protection Agency (EPA), "Waters of the United States" (WoUS) are regulated in compliance with Section 404 of the Clean Water Act (33 U.S.C. 1344). In arid-land stream channels, the WoUS are delineated as the extent of the ordinary high water mark (OHWM). Establishing the extent of the OHWM is often difficult because of the variable conditions that the streams regularly endure. Arid streams are frequently impacted by short-term, high-intensity or "flashy" events that occur between periods of drought. It is important to understand how vegetation and stream channel morphology respond to various discharge events.

In this project, we examined sequential aerial photographs and stream gauge data for eight ephemeral and intermittent streams in the Arid West. By analyzing aerial photos from before and after discharge events, we tried to identify how low to moderate discharges typically associated with delineating the OHW (Lichvar and McColley 2008) impact the vegetation within a variety of watersheds.

In particular, this study was addressing the following questions:

- Can we see a difference in the stream morphology or vegetation spatial arrangements as a result of a discharge event, regardless of the size of that event?

- If so, is the change in stream morphology or vegetation patterns different for larger vs. smaller events?

- Is this a useful tool for interpreting and supporting OHW delineations using various remote sensing resources?

- Do the results of evaluating the channel morphology and vegetation responses for various discharge events support the published OHW methodology (Lichvar and McColley 2008)? 


\section{Background}

\section{Arid West streams}

In the Arid West the vegetation along stream corridors can vary drastically from the surrounding upland vegetation, in part because of hydrologic influences along the stream corridor (Lichvar and Wakeley 2004). Arid West streams often do not have a continuous flow; instead these streams rely primarily on storm events, which can be flashy and have dramatic effects on the channel morphology by depositing or removing large amounts of sediment. The majority of streams in the Arid West are intermittent and ephemeral, and their appearance and morphology are a result of flashy events rather than a sustained continuous flow as in more humid environments (Lichvar and Wakeley 2004). The hydrologic regime of intermittent streams depends on water from springs or surface runoff, whereas ephemeral streams are influent, their water flow feeds groundwater, and therefore they only flow during and immediately after storm events, except in areas where stream channels are used to divert and/or disseminate seasonal irrigation (Gordon et al. 2004, Levick et al. 2008).

Channel morphology is influenced by the hydrologic regime and by the tendency of the channel to establish a state of equilibrium (Field and Lichvar 2007). These components drive the quantity of sediment deposited and eroded in the channel, in turn influencing the geometry of the channel and the surrounding floodplain. Common fluvial features typical of the perennial channel and floodplain include a bankfull channel, the active floodplain, and the terrace floodplain (Figure 1).

However, in the Arid West, studies suggest that intermittent and ephemeral streams do not have separate bankfull channels and active floodplains; instead the bankfull and active floodplain combine to make one active floodplain where the majority of work occurs (Lichvar and McColley 2008). While this study does support this theory, for the purpose of the study methodology, the bankfull channel and the active floodplain were analyzed as separate units so that differences in response features could be observed. 


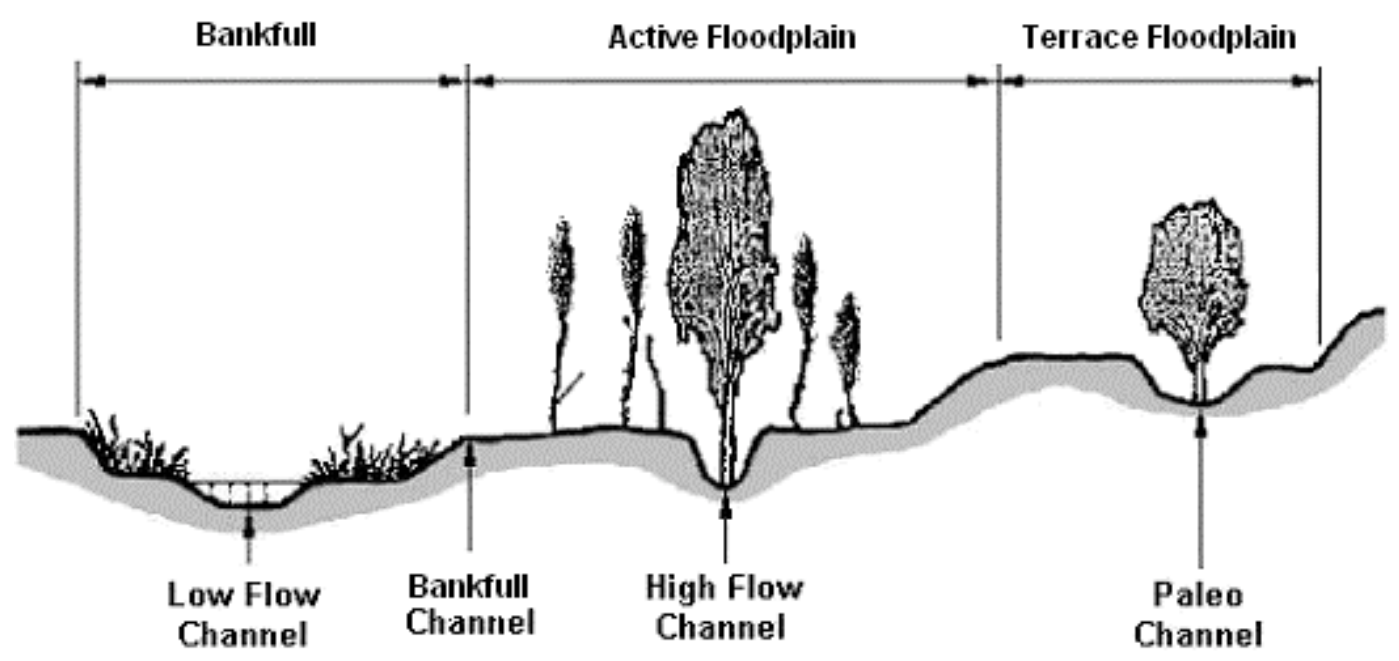

Bankfull ..........1 to 2 year return interval (regulated as wetland or WoUS) Active Floodplain ...........ess than 10 year return interval (regulated as wetland WoUS) Terrace Floodplain ..........10 to 100 year floodplain (partially regulated andior FEMA)

a. Perennial channel forms.

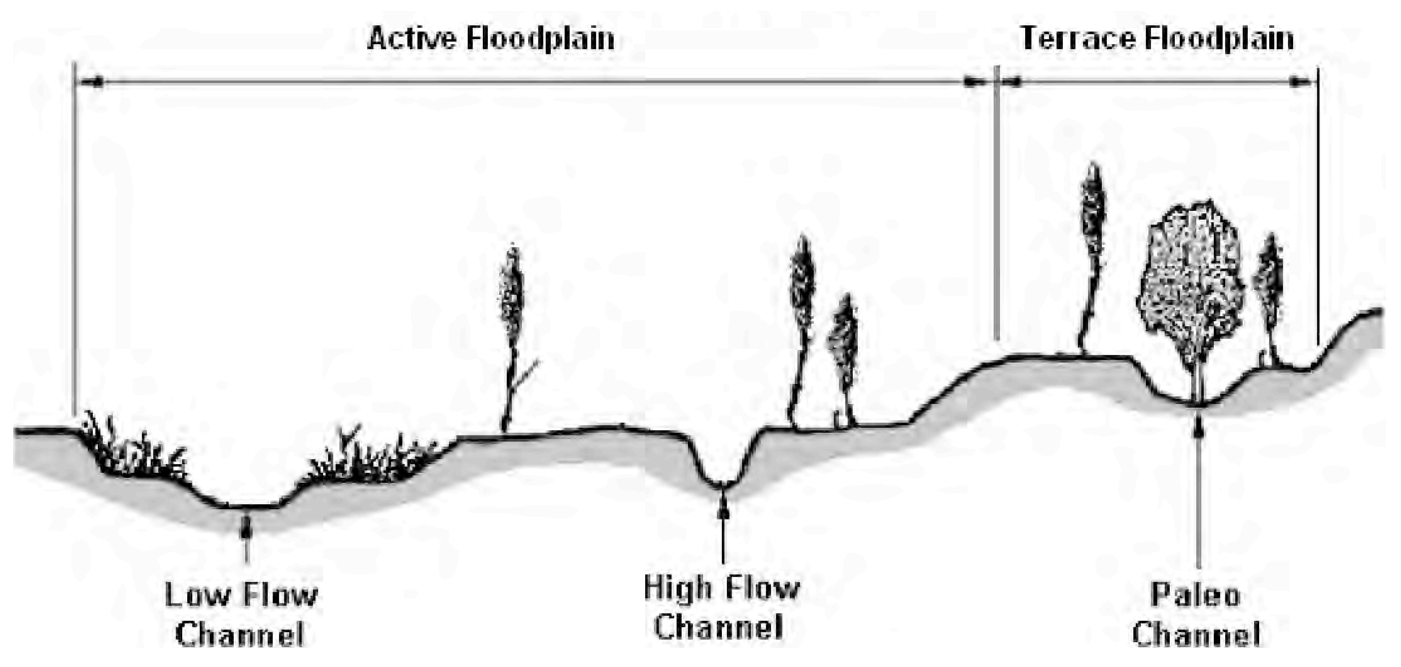

b. Intermittent and ephemeral channel forms.

Figure 1. Typical cross section depicting hydrogeomorphic floodplain units for typical streams.

In intermittent and ephemeral streams, low-flow channels in the active floodplain differ from the bankfull channel of perennial streams. In the Arid West, the low-flow channel of an intermittent or ephemeral stream will form and relocate during low to moderate discharge events (5-10 years) instead of being maintained by continuous flows, as in perennial streams. This channel is unstable because flashy discharge events alter the hydrologic regime and because sedimentary deposits and erosional features throw the system into imbalance. 


\section{Stream types}

There are five main channel types found throughout the U.S.: discontinuous ephemeral streams, compound channels, single-thread channels, alluvial fans, anastamosing rivers, and single-thread channels with adjacent floodplains (Field and Lichvar 2007). Table 1 describes the conditions under which each of these channels develop. During this study, only compound channels, discontinuous ephemeral streams, and singlethread channels were sampled.

Table 1. Natural controls on fluvial processes (from Lichvar and McColley 2008).

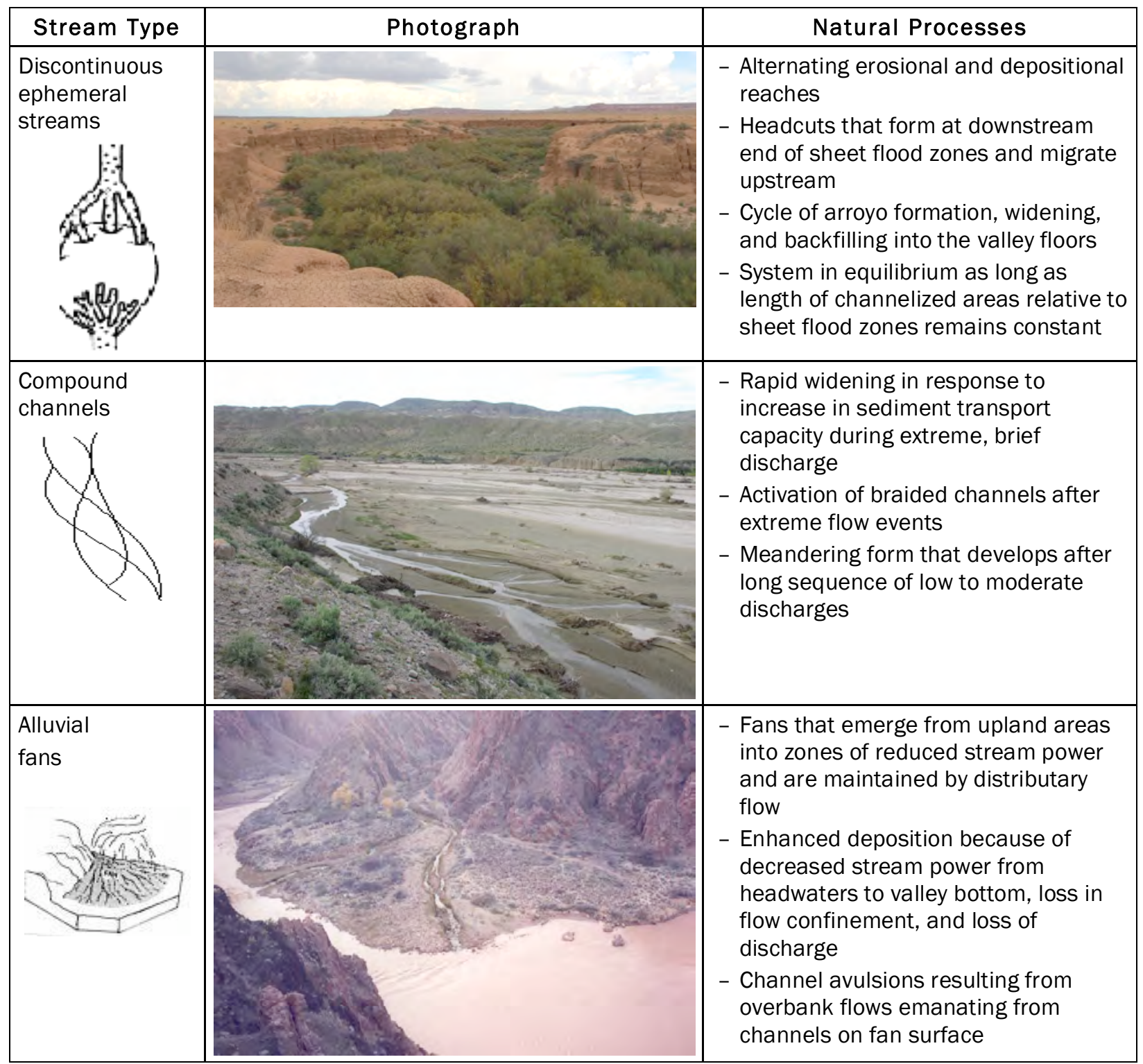


Table 1 (cont.). Natural controls on fluvial processes (from Lichvar and McColley 2008).

\begin{tabular}{|c|c|c|}
\hline Stream Type & Photograph & Natural Processes \\
\hline $\begin{array}{l}\text { Anastamosing } \\
\text { rivers }\end{array}$ & 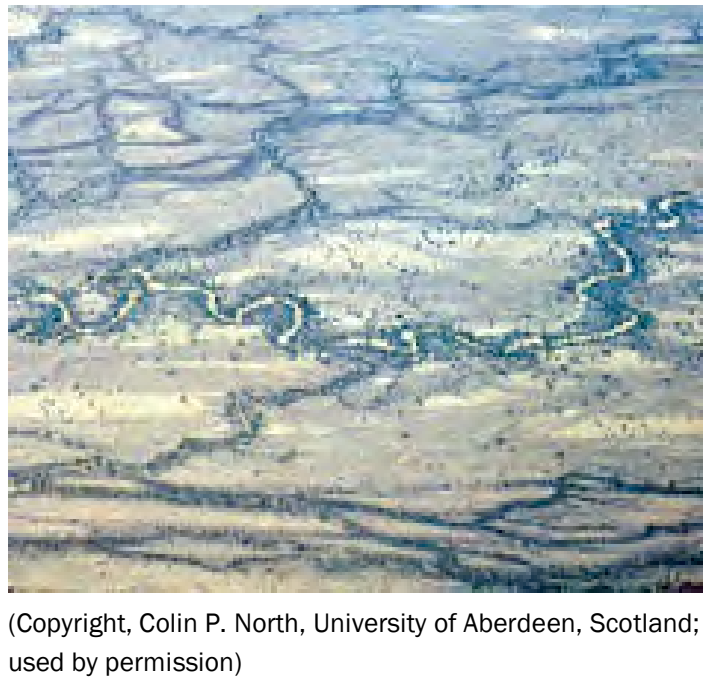 & $\begin{array}{l}\text { - Frequent channel avulsions } \\
\text { - Smaller anabranch channels that } \\
\text { grow headward towards the main } \\
\text { channel in response to overbank } \\
\text { flows emanating from aggrading main } \\
\text { channel }\end{array}$ \\
\hline $\begin{array}{l}\text { Single-thread } \\
\text { channels with } \\
\text { adjacent } \\
\text { floodplains }\end{array}$ & 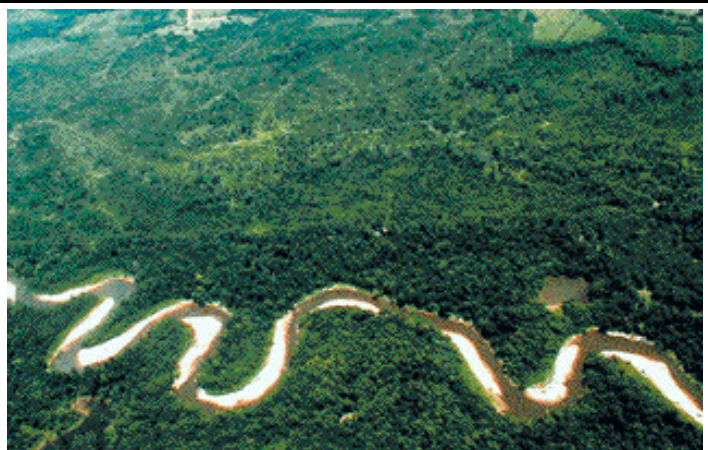 & $\begin{array}{l}\text { - Meandering that develops to } \\
\text { minimize amount of change at any } \\
\text { point along river } \\
\text { - Channel incision when sediment } \\
\text { transport capacity of reach is elevated } \\
\text { relative to sediment supplied to reach } \\
\text { - Channel widening with bank } \\
\text { destabilization } \\
\text { - Aggradation due to decrease in } \\
\text { capacity to transport sediment }\end{array}$ \\
\hline
\end{tabular}




\section{Methods}

In an initial screening of potential study sites in the Arid West (Figure 2), we located 50 ephemeral and intermittent streams that have U.S. Geological Survey (USGS) gauge data and ample aerial photographic information to assess patterns of change associated with discharge events. Sites were further reduced based on these criteria:

- There were at least 10 years of hydrology data;

- The site locations fit within the Arid West ecologic region defined by the USACE Arid West manual (U.S. Army Corps of Engineers 2006);

- There was minimal anthropogenic modification; and

- The site was accessible.

Hydrologic data for each site were obtained from the USGS Web site (http://waterdata.usgs.gov/nwis/sw). Anthropogenic modification was evaluated from aerial photos and qualifiers within the USGS hydrology data. Using these four criteria, we narrowed down the original list of 50 sites to 30. We narrowed the list further based on the availability and quality of aerial photography. At least two aerial photos were necessary to determine the impacts of discharge events; this requirement reduced the site selection to 17 streams. To be able to correlate a change in vegetation pattern with a discharge event, we looked at the 17 sites to find those that had pairs of photos bracketing single three-year discharge events. This reduced the number of acceptable sites to eight (Figure 3). Appendix A shows the characteristics of the eight sites. Appendix B shows how the timing of the aerial photos relate to the timing and size of discharge events. 


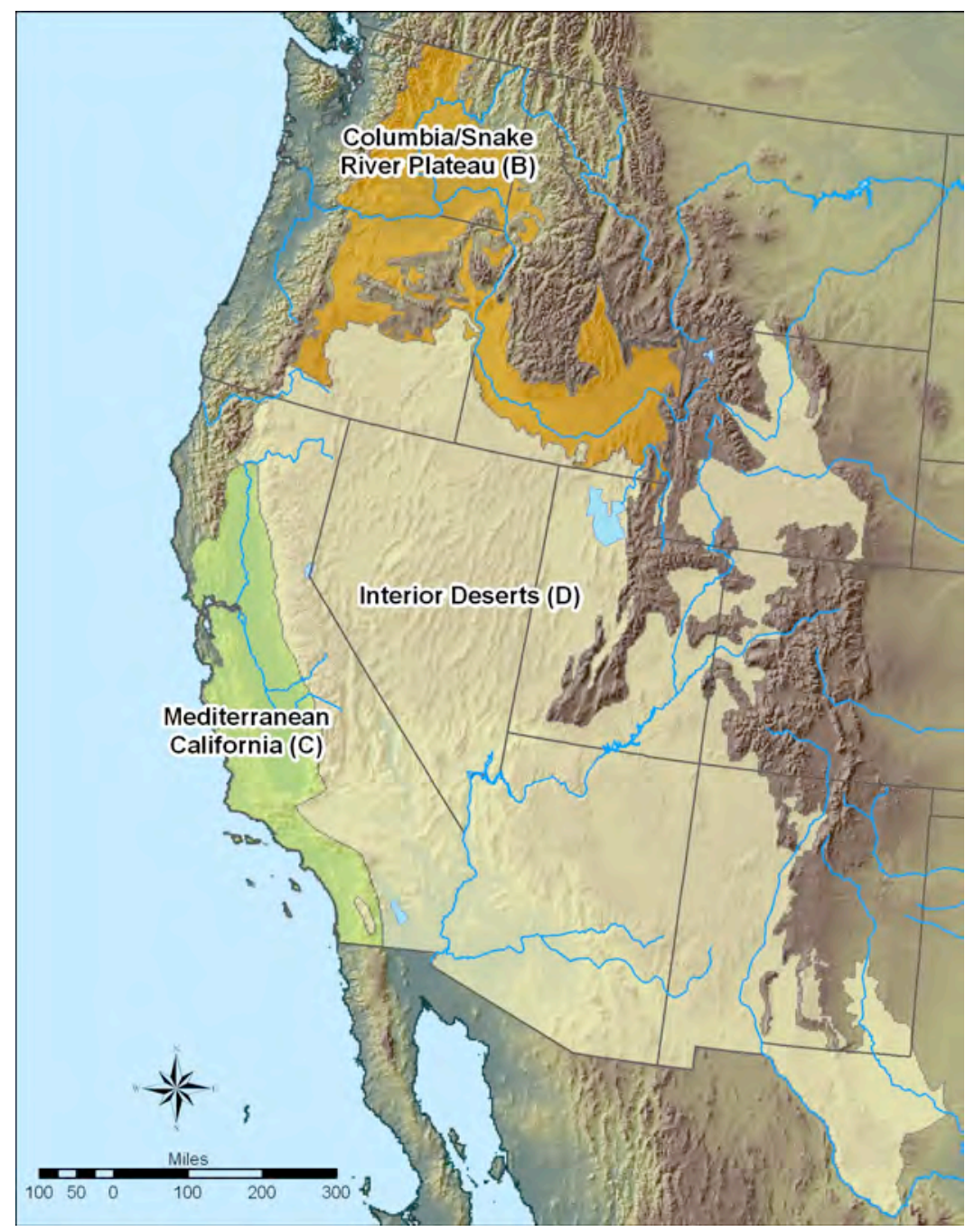

Figure 2. The Arid West region as defined by Land Resource Regions (LRR) B, C, and D (USDA Natural Resources Conservation Service 2006). 


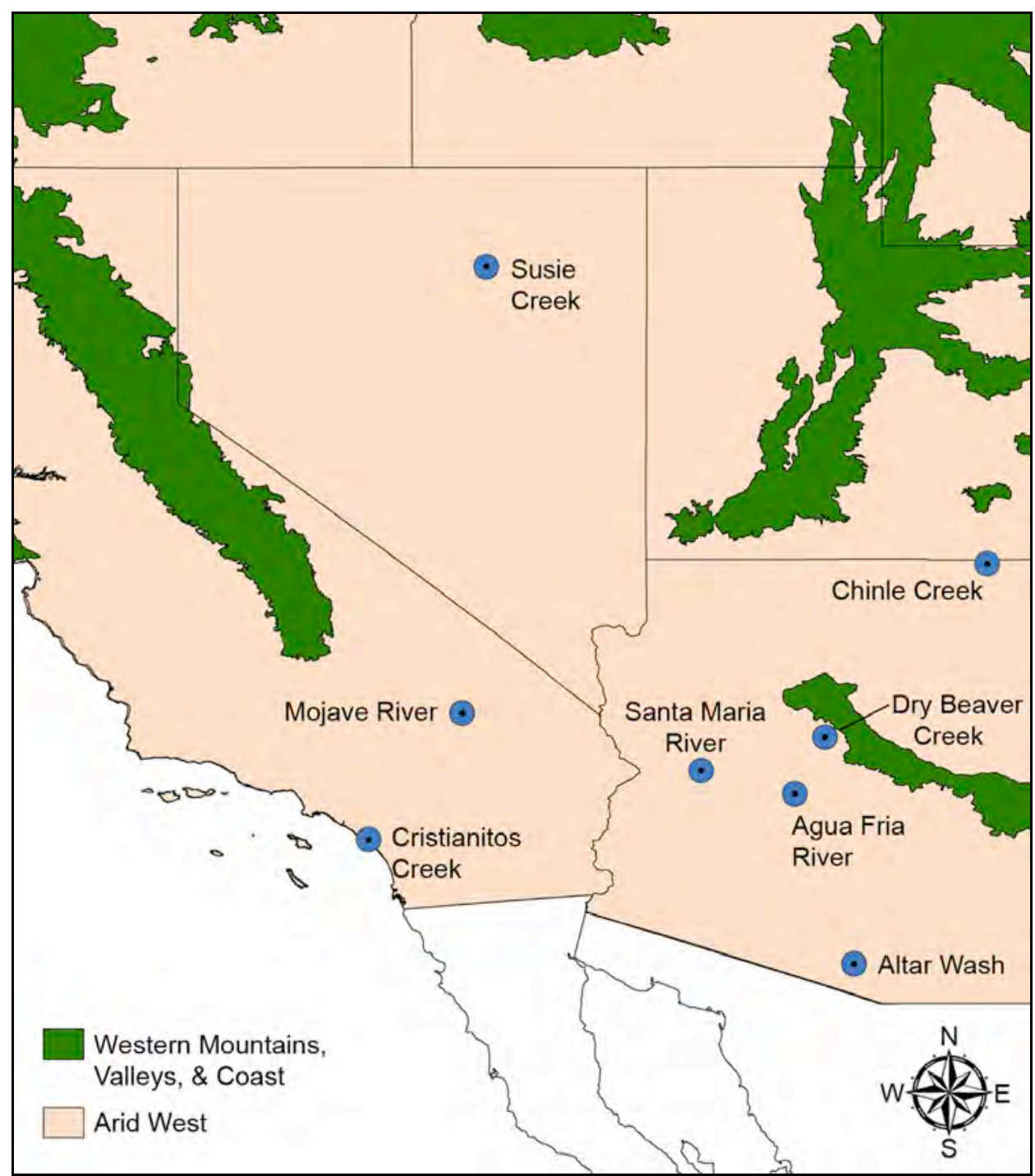

Figure 3. Site stream locations overlaid with land resource regions.

Information collected for each of the eight ephemeral and intermittent streams included aerial photography with year, years between pictures, direction of stream flow, average flood frequency between pictures, and the response of vegetation to discharge events. All acquired photos were Digital Orthophoto Quarter Quadrangles (DOQQs), and aerial photographs were from USGS National High Altitude Aerial Photography Program (NHAPP) or National Aerial Photography Program (NAPP). All aerial photographs were labeled with the year of acquisition; the date within the year was not always available from NHAPP and NAPP. Imagery varied greatly depending on whether the aerials were obtained from satellite or airplane, the film used, the scale of the image, and the orientation of the image. Peak flow analysis was used to determine flood frequency (called discharge events hereafter), which was calculated using 
data from the USGS website (http://waterdata.usgs.gov/nwis/sw) following Bulletin 17B Guidelines (Interagency Advisory Committee on Water Data 1982).

To assess the impact of a discharge event on the eight chosen sites, we determined the change in the channel upstream from the stream gauge by viewing one aerial image prior to a discharge event and one aerial image after that discharge event (Figure 4). For each site, both before and after the flood event, riparian corridors were delineated for various channel features using the digital imagery within ArcView GIS (geographic information system) 3.2 and ArcMap 9.2. All mapping was done at a scale of 1:2,400 representative fraction. To better locate and identify surfaces, we used support spatial databases, including topography maps from the U.S. Geological Survey and contour lines that were created within ArcMap.

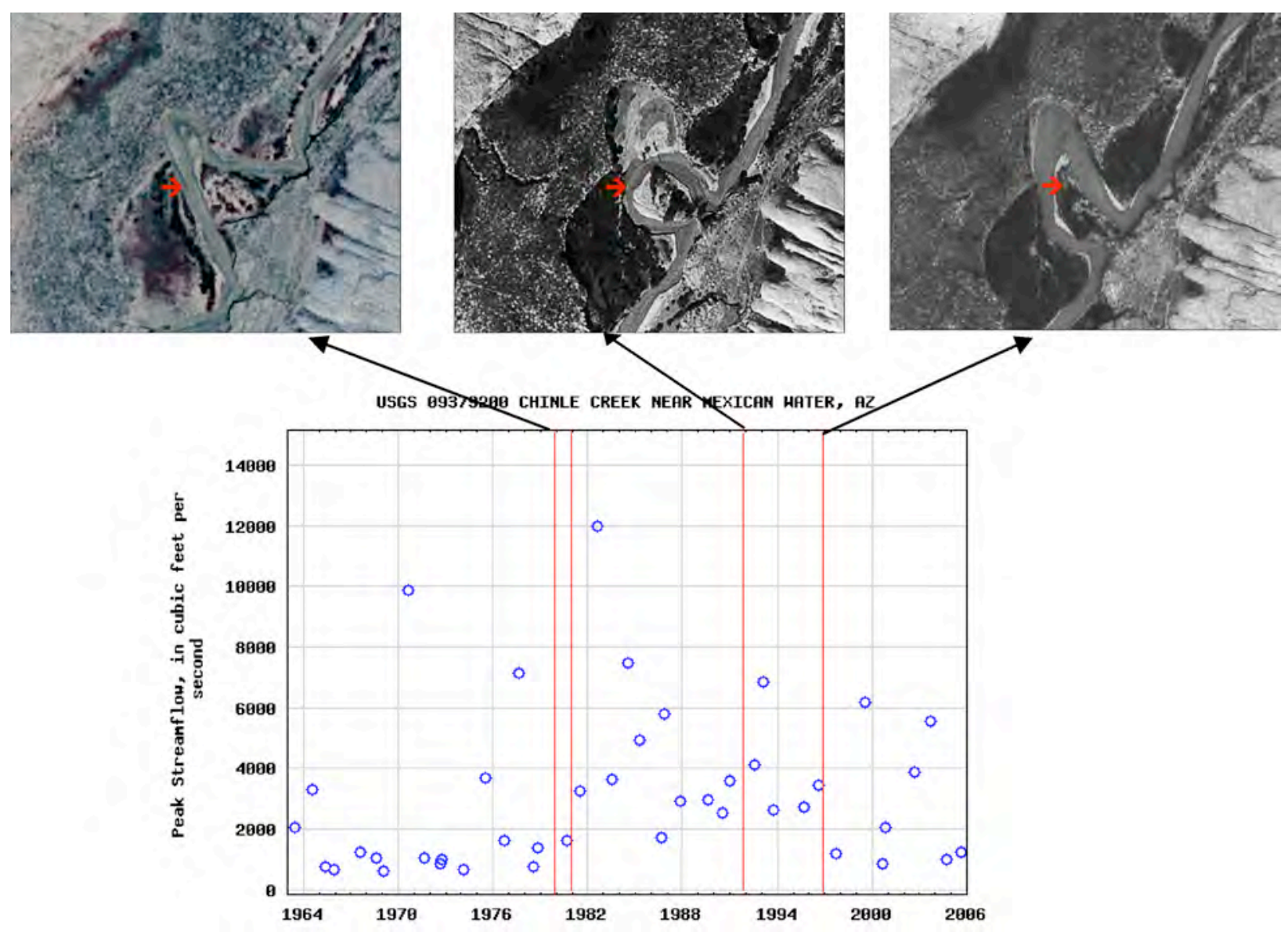

Figure 4. Chinle Creek near Mexican Water, AZ. The red arrow shows the shift in the channel from 1981, 1992, and 1997. The second two photos were used in this analysis. 
We mapped the hydrogeomorphic surfaces representing the bankfull channel and the active and terrace floodplains on the aerial images. The bankfull channel and the active floodplain contain features associated with frequent flooding, including high-flow channels, unvegetated surfaces, bed and bank, and a break in slope. The terrace floodplain is above the active floodplain and contains features associated with infrequent flooding and seasonally wet areas, including increases in vegetation cover, surface relief, and surface rounding. Often there is a distinct change in vegetation at the boundary between the active and terrace floodplains (Figure 5). Within these hydrogeomorphic surfaces, the vegetation was mapped and characterized as either bare/herb or shrub/tree. The vegetation type could not be determined more specifically because of the quality and scale of the images.

Once the hydrogeomorphic surfaces and vegetation boundaries were mapped, we calculated the areas for the bankfull channel and the active and terrace floodplains and for the vegetation within each of the hydrogeomorphic zones. From the areas occurring in each zone, we calculated percentages for each surface and vegetation type. We could then determine the changes in area between the two photos in each pair. 


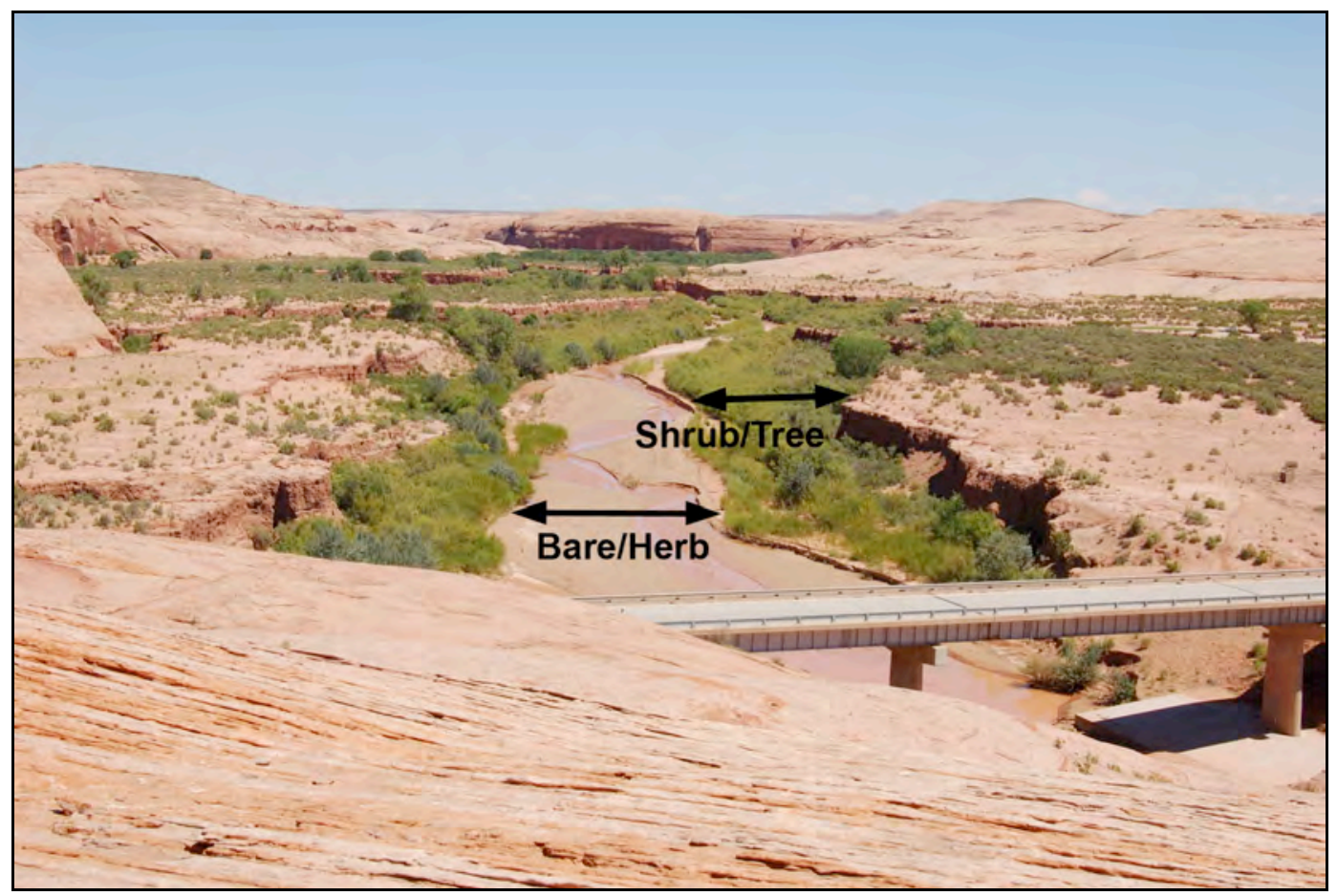

a. Chinle Creek

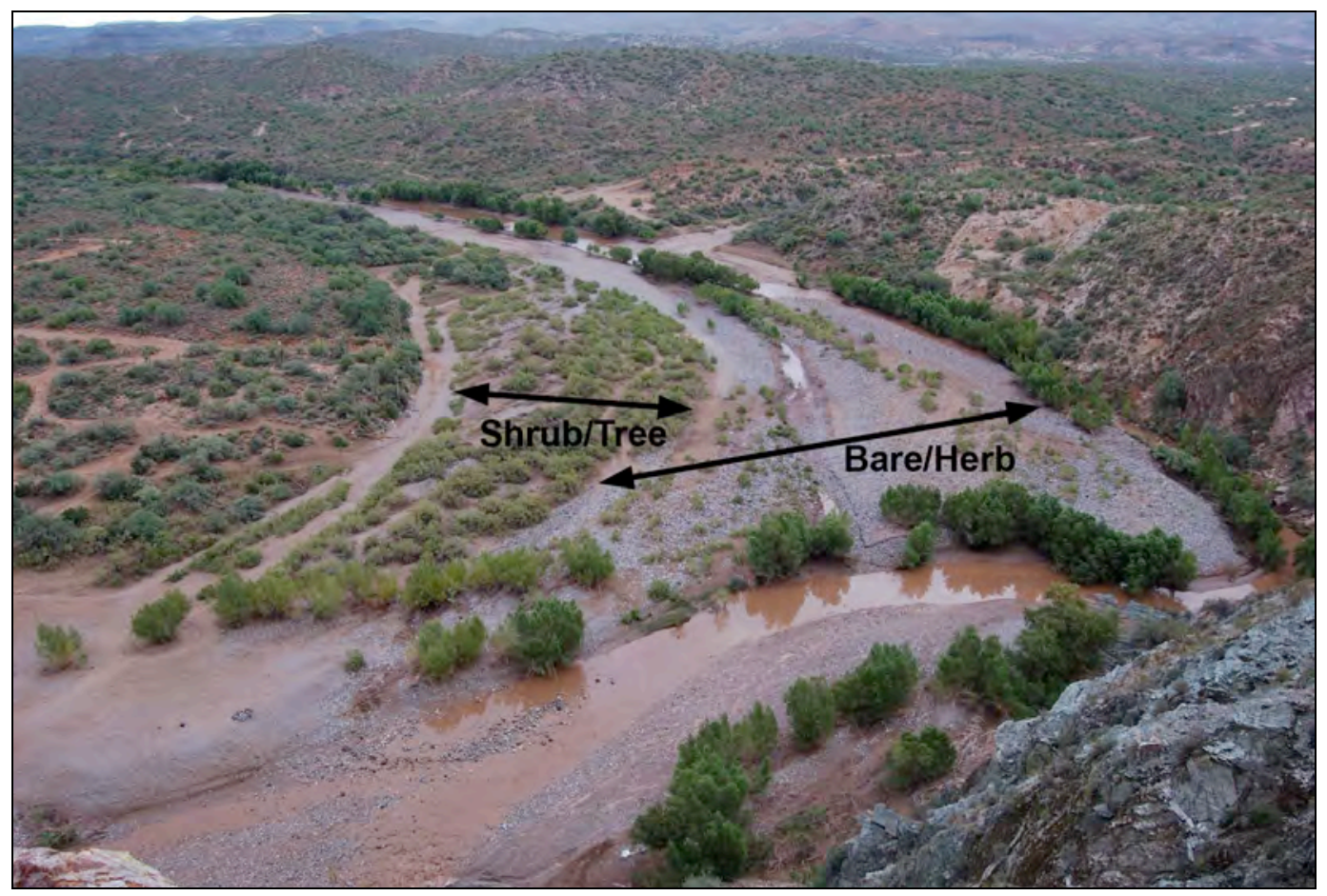

b. Agua Fria

Figure 5. Vegetation categories at two sites. 


\section{Results}

The aerial photos and the hydrogeomorphic and vegetation delineations are shown in Appendix C. Appendix D contains the data extracted from the delineations. Figures 6 and 7 and Table 2 show summaries of the data for all sites, for sites with low-discharge events, and for sites with moderatedischarge events.
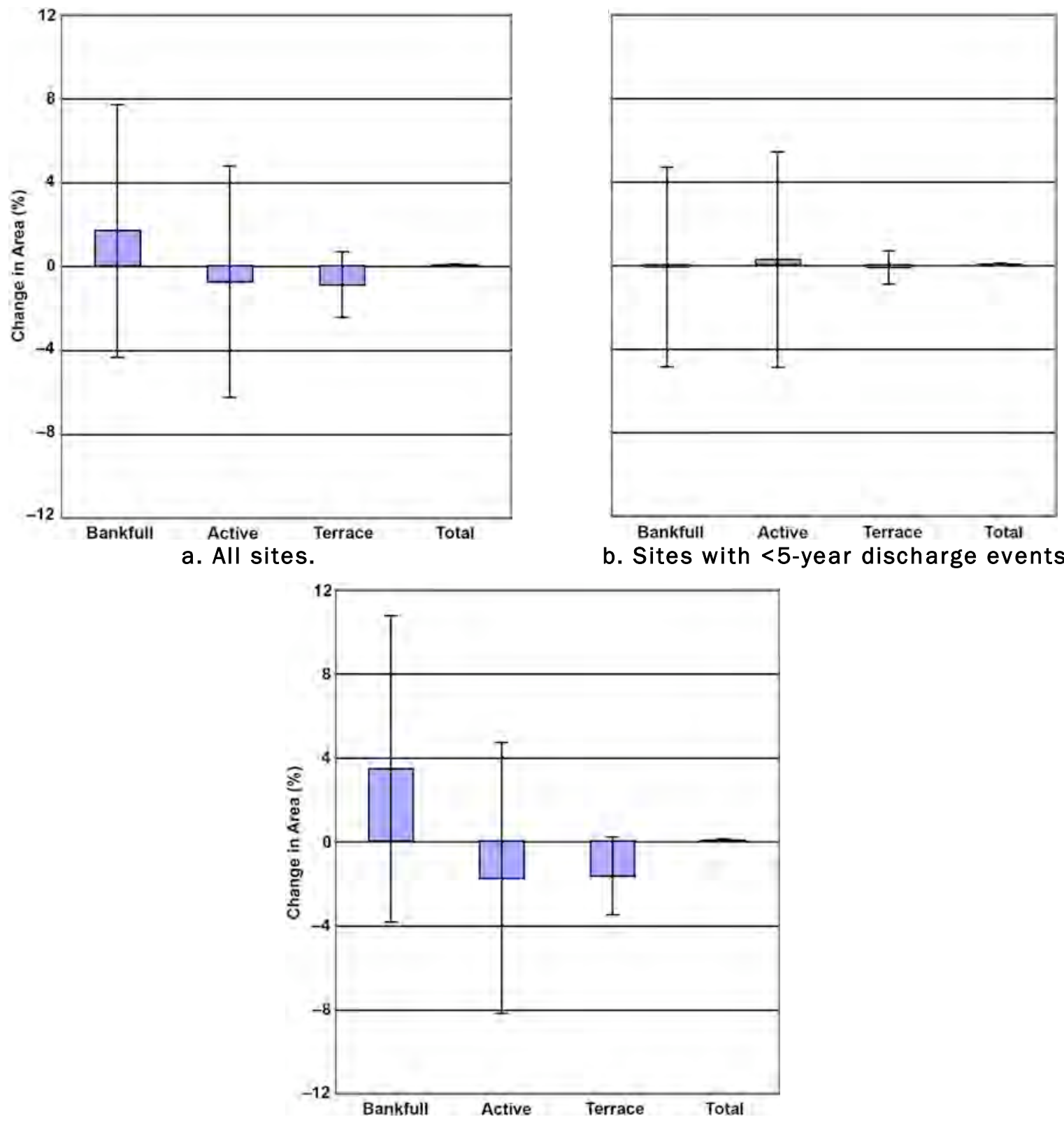

c. Sites with >5-year discharge events.

Figure 6. Mean changes in channel morphology zones ( \pm one standard deviation). 


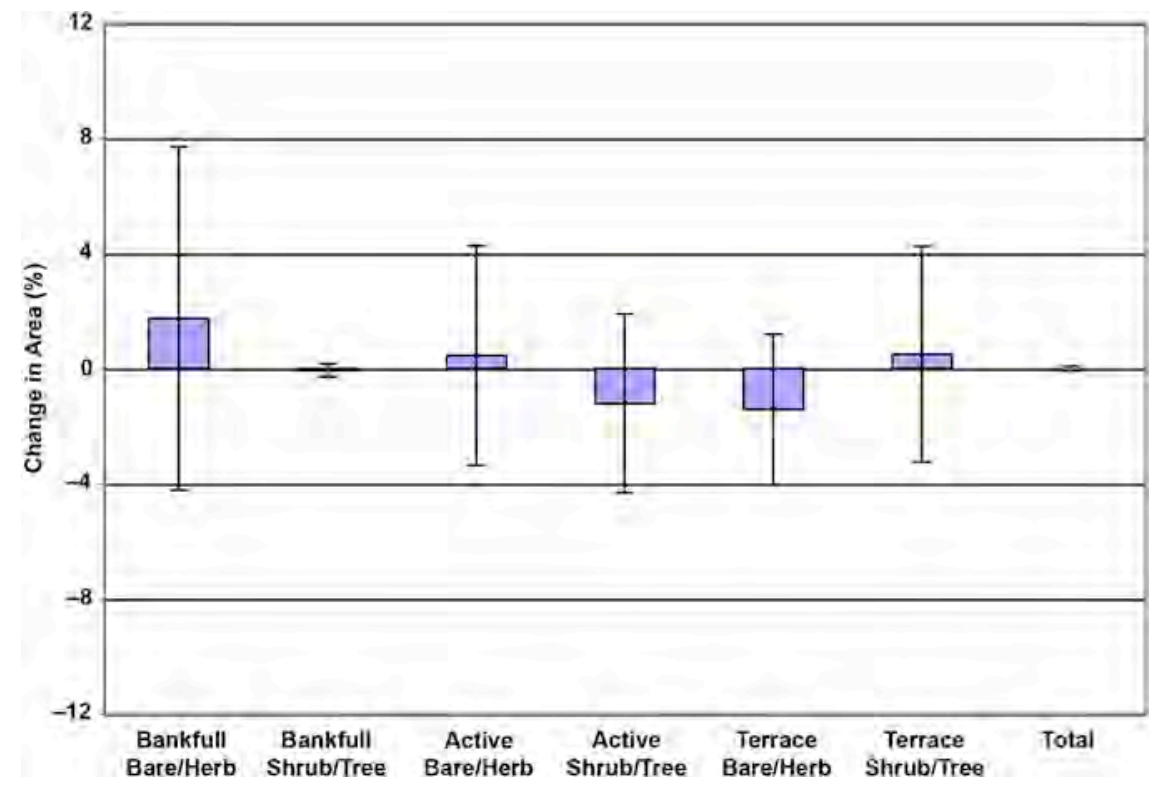

a. All sites.

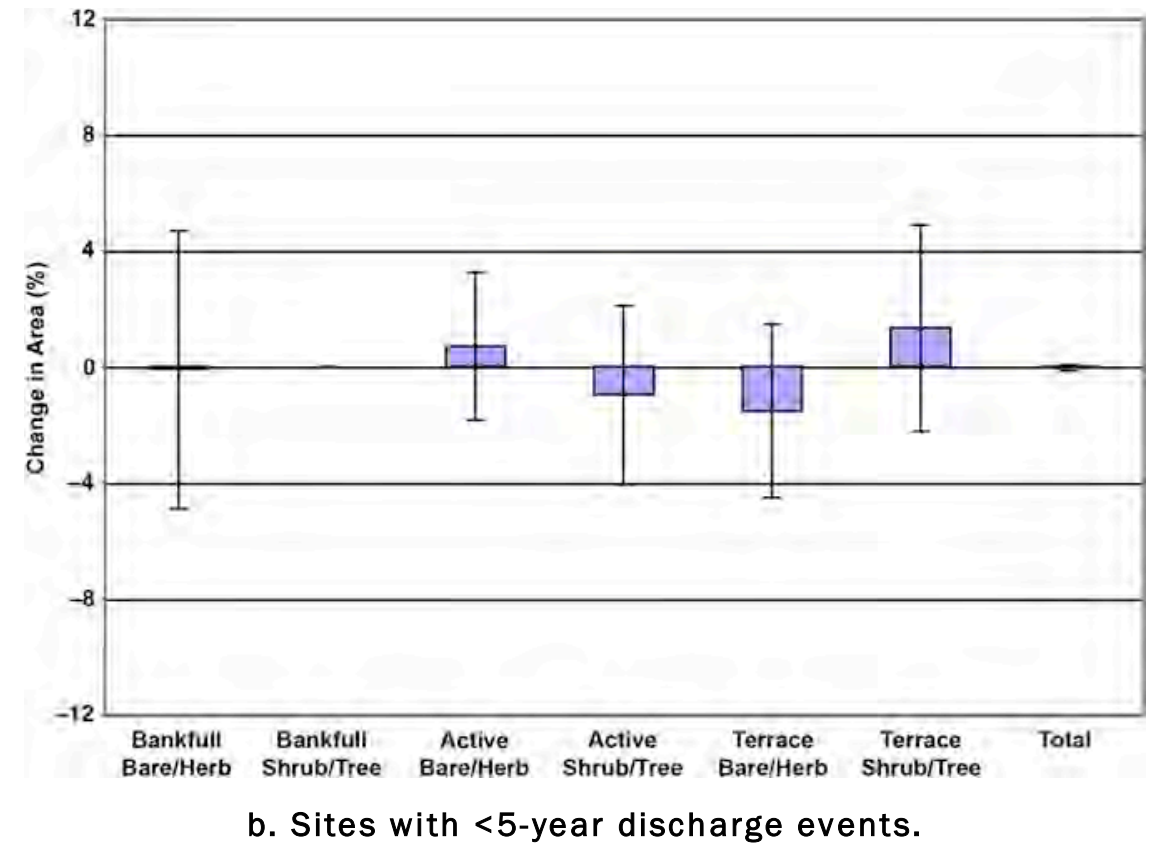

Figure 7. Mean changes in vegetation for all sites ( \pm one standard deviation). 


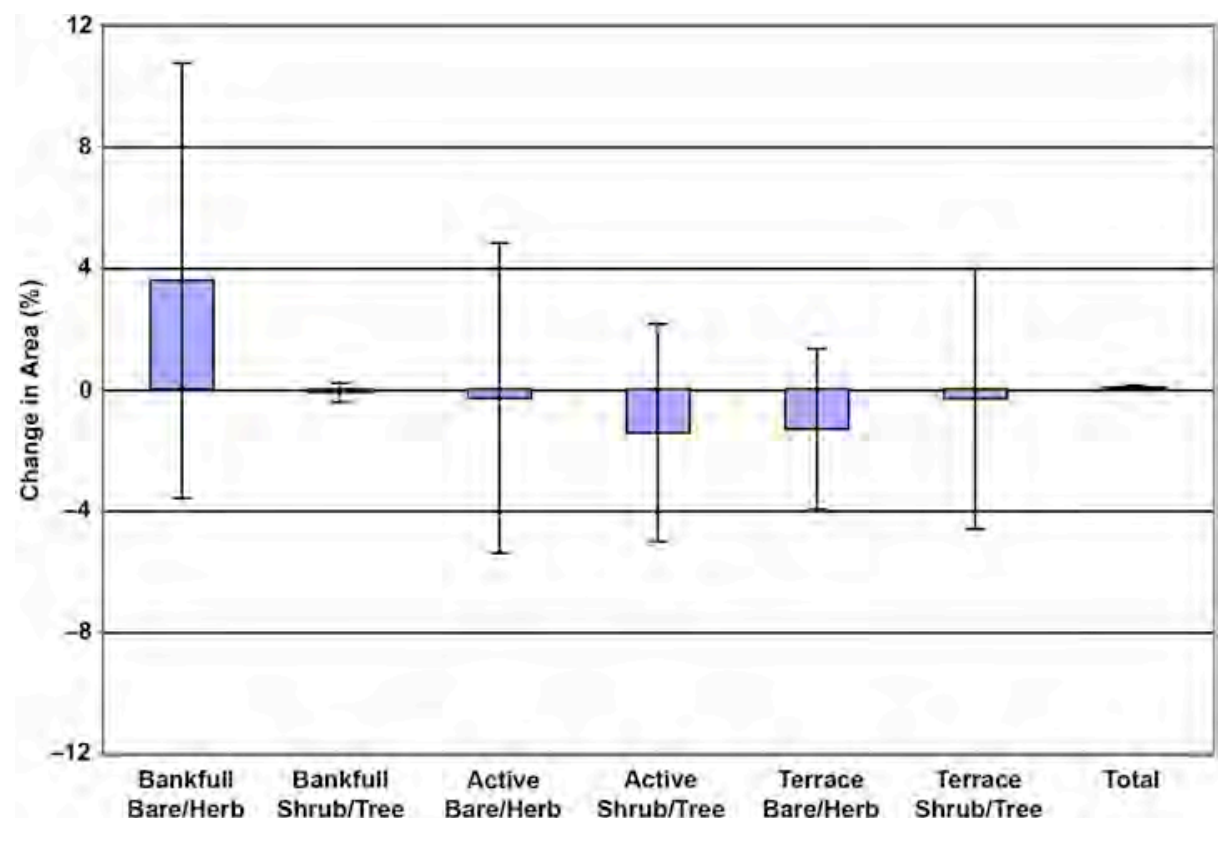

c. Sites with $>5$-year discharge events.

Figure 7 (cont.) Mean changes in vegetation for all sites ( \pm one standard deviation).

Table 2. Percent change in area between photo pairs for channel morphology zones and vegetation for all sites and for those with flood return intervals of fewer than or greater than 5 years.

\begin{tabular}{|l|c|c|c|c|c|c|}
\hline \multirow{2}{*}{} & \multicolumn{7}{|c|}{ Average change (\%) } \\
\cline { 2 - 7 } & \multicolumn{2}{|c|}{ All Sites } & \multicolumn{2}{c|}{$\begin{array}{c}\text { Discharge events } \\
<5 \text { years }\end{array}$} & \multicolumn{2}{c|}{$\begin{array}{c}\text { Discharge events } \\
>5 \text { years }\end{array}$} \\
\cline { 2 - 7 } & Mean & SD & Mean & SD & Mean & SD \\
\hline Bankfull & 1.68 & 6.02 & $-0.10 *$ & 4.78 & 3.45 & 7.30 \\
\hline Active & -0.75 & 5.51 & 0.25 & 5.15 & -1.75 & 6.45 \\
\hline Terrace & -0.89 & 1.54 & -0.12 & 0.80 & -1.65 & 1.84 \\
\hline Total & 0.04 & 0.05 & 0.02 & 0.05 & 0.05 & 0.06 \\
\hline Bankfull-Bare/Herb & 1.74 & 5.97 & -0.10 & 4.78 & 3.58 & 7.16 \\
\hline Bankfull-Shrub/Tree & -0.06 & 0.22 & 0.00 & 0.00 & -0.13 & 0.32 \\
\hline Active-Bare/Herb & 0.46 & 3.82 & 0.70 & 2.53 & -0.30 & 5.10 \\
\hline Active-Shrub/Tree & -1.21 & 3.10 & -0.98 & 3.07 & -1.45 & 3.59 \\
\hline Terrace-Bare/Herb & -1.43 & 2.62 & -1.53 & 2.99 & -1.33 & 2.65 \\
\hline Terrace-Shrub/Tree & -0.50 & 3.75 & 1.33 & 3.55 & -0.33 & 4.28 \\
\hline Total & 0.00 & 0.09 & -0.05 & 0.10 & 0.05 & 0.06 \\
\hline & & & & & & \\
Mean flood return interval & 6.91 & 5.20 & 3.50 & 0.57 & 10.33 & 5.63 \\
\hline
\end{tabular}

*Negative values indicate a loss of size or spatial coverage. 


\section{Discussion}

\section{Channel morphology and vegetation changes}

The measurements of area for each fluvial zone generally showed small differences in channel morphology and vegetation response as a result of discharge events. The bare/herb area of the bankfull and active zones increased or stayed the same, whereas the shrub/tree area of those zones decreased or stayed the same (Figure 7). This supports the concepts that the bankfull channel is less stable and moves around more frequently and that small to moderate discharge events remove more vegetation and transport more fluvial material in this zone. This pattern of responses fits the reactions of the intermittent/ephemeral channels in the Arid West, where the bankfull and active channels are frequently reconfigured by the movement and deposition of materials as a result of geomorphically effective discharge events in the active zone. In the terrace, bare/herb areas decreased while shrub/tree areas stayed the same or increased, implying that the discharge events had little effect and that normal, longterm vegetation successional processes were dominant.

The discharges on these channels expressed two patterns of response. The first was that the largest amount of change is within the bankfull zone, and the second is that less change occurs at the outer boundary of the active zone (Table 2). For discharge events less than 5 years, there was little change in channel morphology or vegetation. For events greater than 5 years, the bankfull channel got larger or was relocated, whereas the other zones either stayed the same or got slightly smaller. For discharge events greater than 5 years, the bare/herb area in the bankfull channel increased. These 5- to 10-year discharges in Arid West intermittent/ephemeral channels have been described as geomorphically effective events (Field and Lichvar 2007); that is, they clean out the channel, move material, and maintain the active channel appearance. Small events have almost no impact on the bankfull or active channel zones.

Changes in area represent several patterns of shifts in the channels. The aerial photos show that zone boundaries can shift to some degree without significant changes in area; that is, the zones can change in morphological design but still cover the same area. At the Mojave site, the areas of the 
three zones were nearly constant, but the aerial photos show that the bankfull channel was relocated by a low to moderate discharge event. In fact, the bankfull channel at several sites shifted locations and in some cases became small or nonexistent. This supports Lichvar and McColley's (2008) concept that the bankfull channel develops in the final drawdown stages of a geomorphically effective discharge event in the active zone rather than being a separate stable geomorphic unit, so that what is typically called the bankfull zone is actually a low-flow channel within the active floodplain.

The active/terrace interface margins were much more stable than the bankfull margins. Regardless of the size of the discharge event, the boundaries between the active and terrace zones remained relatively stable. (An exception is the Cristianitos site, where there's no bankfull channel and the active/terrace boundary changed in places, although the relative areas didn't change much.) Appendix E contains ground photos showing active/terrace boundaries at several sites.

\section{Variability}

Our sample size was not large; we started with 50 potential sites, but only eight met all our selection criteria. It is impossible to tell from our data if the amount of variability we saw was a result of the small sample size or is inherent to ephemeral/intermittent channels in the Arid West. However, in over a decade or more of field studies, we have observed and mapped channel morphological features in thousands of these types of channels in the Arid West and have found that these patterns of responses are typical and repeating.

Other variables can affect the vegetation and channel morphology; this study only accounted for some. In particular, we did not consider the influences of the geology and parent material in a watershed, the landscape position of the channels, the channel morphology, the size of the watershed, the land use within the watershed, or the recovery time before the second photo, any of which could contribute to the variability. However, hydrologic modeling (Lichvar et al. 2006) and extensive field observations suggest that the size of the discharge event is the most significant variable influencing the responses we see.

The amount of variability, as indicated by the size of the error bars in Figures 6 and 7, is consistent with our understanding of the dynamics of 
ephemeral/intermittent channels in the Arid West. Figure 6 shows, for channel morphology, high variability for the area of the bankfull and active zones and low variability for the terrace. Since there was only one discharge event larger than 10 years, this is as expected; the events had little effect on the morphology of the terrace. For vegetation (Figure 7), the variability in the various categories was similar (except for shrub/tree in the bankfull zone, which makes sense because there were very few shrubs or trees in that zone).

\section{Tool for OHW determination}

In general, the results of this study support the OHW delineation methodology for establishing the lateral extent of the OHW position used by the U.S. Army Corps of Engineers and the U.S. Environmental Protection Agency (Lichvar and McColley 2008) under the Clean Water Act by indicating that the active/terrace margin is the most consistently stable and positioned feature that allows for a repeatable delineation result. In contrast, the bankfull zone is not the same functioning channel unit as in perennial systems and is much less stable and reliable as a delineation feature. The active floodplain does therefore represent a zone that most closely fits the concept of "ordinary" discharges for use in delineating the $\mathrm{OHW}$ limits.

To test the strength of our technique, we compared the total areas delineated for each fluvial zone in each pair of photos. We assumed that the outer edge of the terrace should stay the same, because there were no discharge events in our study watersheds during our study period that were large enough to affect this part of the channel. Differences in the total area delineated were presumably the result of differences in photo quality and the difficulty in being precise in delineations. The differences ranged from $+2.5 \%$ at Agua Fria to $-7.8 \%$ (representing a loss in area) at the Santa Maria River; the other sites had differences of less than $1.5 \%$ and the mean for all sites was 2.0\%. This indicates that we can expect variations in any channel morphology or vegetation category of $1-2 \%$ or more based simply on the technique, regardless of the reality on the ground. 


\section{Conclusion}

With the need under the Clean Water Act to delineate intermittent and ephemeral streams in the Arid West, we feel that the use of remotely sensed resources greatly assists with offsite delineations of channel features of the $\mathrm{OHW}$ by reducing the time investment and improving the interpretation of the position of the OHW made during onsite visits.

The results of this study consistently show that the majority of work, whether it affects vegetation or channel morphology, occurs within the bankfull channel and active floodplain. This study also showed that the terrace floodplain maintained its vegetative and morphology composition with discharges as large as an 18.7-year flood event, the largest we studied. Data analyzed by flood events support the theory that the bankfull and active channels of intermittent and ephemeral streams in the Arid West function as one channel and that the outer boundary of this single channel represents the extent of the OHW.

This initial study had a small sample size due to study design criteria and did not account for several relevant variables, yet the results are consistent with the protocols presented in the Corps' OHW manual. With additional research and a larger sample size, we believe that stream morphology and vegetative response patterns and their relationships to types of discharge events for the bankfull and active channels and the terrace floodplain will fall more discretely into their distinct categories. 


\section{References}

Field, J., and R. Lichvar. 2007. Review and synopsis of natural and human controls on fluvial channel processes in the Arid West. ERDC/CRREL TR-07-16. Hanover, NH: U.S. Army Engineer Research and Development Center, Cold Regions Research and Engineering Laboratory. (http://www.crrel.usace.army.mil/techpub/CRREL Reports/reports/TRo716.pdf).

Gordon, N. D., T. A. McMahon, B. L. Finlayson, C. J. Gippel, and R. J. Nathan. 2004. Stream hydrology: An introduction for ecologists. Second edition. West Sussex, England: John Wiley and Sons Ltd, The Atrium, Southern Gate, Chichester.

Interagency Advisory Committee on Water Data. 1982. Guidelines for determining flood flow frequency. Bulletin 17B. Reston, VA: Hydrology Subcommittee, Office of Water Data Coordination, U.S. Geological Survey.

Levick, L. R., D. C. Goodrich, M. Hernandez, J. Fonseca, D. J. Semmens, J. Stromberg, M. Tluczek, R. A. Leidy, M. Scianni, D. P. Guertin, and W. G. Kepner. 2008. The ecological and hydrological significance of ephemeral and intermittent streams in the arid and semi-arid American Southwest. EPA/600/R-08/134, ARS/233046. U.S. Environmental Protection Agency and USDA/ARS Southwest Watershed Research Center.

Lichvar, R. W., and S. M. McColley. 2008. A field guide to the identification of the Ordinary High Water Mark (OHWM) in the arid west region of the western United States. ERDC/CRREL TR-o8-12. Hanover, NH: U.S. Army Engineer Research and Development Center, Cold Regions Research and Engineering Laboratory.

Lichvar, R. W., and J. S. Wakeley, ed. 2004. Review of Ordinary High Water Mark indicators for delineating arid streams in the southwestern United States. ERDC/CRREL TR-04-1. Hanover, NH: U.S. Army Engineer Research and Development Center, Cold Regions Research and Engineering Laboratory. (http://www.crrel.usace.army.mil/techpub/CRREL_Reports/reports/TRo421.pdf).

Lichvar, R. W., D. Finnegan, M. Ericsson, and W. Ochs. 2006. Distribution of Ordinary High Water Mark (OHWM) indicators and their reliability in identifying the limits of "Waters of the United States" in arid southwestern channels. ERDC/CRREL TR-06-5. Hanover, NH: U.S. Army Engineer Research and Development Center, Cold Regions Research and Engineering Laboratory. (http://www.crrel.usace.army.mil/techpub/CRREL_Reports/reports/TRo65.pdf).

U.S. Army Corps of Engineers. 2006. Interim regional supplement to the Corps of Engineers Wetland Delineation Manual: Arid West Region. J.S. Wakeley, R.W. Lichvar, and C.V. Noble, ed. ERDC/EL TR-o6-16, Vicksburg, MS: U.S. Army Engineer Research and Development Center, Environmental Laboratory. 
USDA Natural Resources Conservation Service. 2006. Land resource regions and major land resources areas of the United States, the Caribbean, and the Pacific Basin. Agriculture Handbook 296. Washington DC: U.S. Department of Agriculture. (http://soils.usda.gov/survey/geography/mlra/index.html) 


\section{Appendix A. Study Locations}

\begin{tabular}{|c|c|c|c|c|c|c|c|c|}
\hline $\begin{array}{l}\text { Gauge } \\
\text { Name }\end{array}$ & Latitude & Longitude & $\begin{array}{l}\text { Flow } \\
\text { direction }\end{array}$ & $\begin{array}{l}\text { Channel } \\
\text { type }\end{array}$ & Division & Geology & Geology detail & Landscape position \\
\hline $\begin{array}{l}\text { Agua Fria } \\
\text { River near } \\
\text { Rock } \\
\text { Springs, AZ }\end{array}$ & 34.01558948 & -112.1679378 & North-South & Compound & $\begin{array}{l}\text { Tropical/ } \\
\text { Subtropical } \\
\text { Steppe }\end{array}$ & $\begin{array}{l}\text { Hard } \\
\text { Rock }\end{array}$ & $\begin{array}{l}\text { Downstream from gauge: } \\
\text { Proterozoic granite; } \\
\text { Upstream: transition to } \\
\text { Quaternary alluvium and } \\
\text { colluvium }\end{array}$ & $\begin{array}{l}\text { Upstream: river runs parallel } \\
\text { to range front in } \sim 1500-\mathrm{ft} \\
\text { foothills; Downstream: river } \\
\text { empties into man-made } \\
\text { reservoir in } 6 \text { miles }\end{array}$ \\
\hline $\begin{array}{l}\text { Altar Wash } \\
\text { near Three } \\
\text { Points, AZ }\end{array}$ & 31.83897238 & -111.4042694 & South-North & $\begin{array}{l}\text { Single Thread/ } \\
\text { Compound }\end{array}$ & $\begin{array}{l}\text { Tropical/ } \\
\text { Subtropical } \\
\text { Desert }\end{array}$ & Soft Rock & $\begin{array}{l}\text { Quaternary alluvium and } \\
\text { colluvium }\end{array}$ & $\begin{array}{l}\text { Gauge is in a flat, dissected } \\
\text { plain }\end{array}$ \\
\hline $\begin{array}{l}\text { Chinle Creek } \\
\text { near Mexican } \\
\text { Water, AZ }\end{array}$ & 36.94389103 & -109.7106684 & $\begin{array}{c}\text { Southwest- } \\
\text { Northeast }\end{array}$ & $\begin{array}{l}\text { Compound/ } \\
\text { Single Thread }\end{array}$ & $\begin{array}{l}\text { Tropical/ } \\
\text { Subtropical } \\
\text { Steppe }\end{array}$ & Soft Rock & Jurassic Navajo sandstone & $\begin{array}{l}\text { In a high plateau }(\sim 5000 \mathrm{ft}) \\
\text { river has cut a canyon into } \\
\text { sedimentary rocks }\end{array}$ \\
\hline $\begin{array}{l}\text { Cristianitos } \\
\text { Creek above } \\
\text { San Mateo } \\
\text { Creek near } \\
\text { San } \\
\text { Clemente, CA }\end{array}$ & 33.42641717 & -117.5703242 & North-South & Compound & California & Soft Rock & $\begin{array}{l}\text { Cretaceous sandstone } \\
\text { bedrock canyons in upper } \\
\text { reaches, Tertiary sandstones } \\
\text { make up middle and lower } \\
\text { reaches with wider valleys } \\
\text { with Quaternary alluvial fill }\end{array}$ & $\begin{array}{l}\text { Gauge is at bottom of } \\
\text { watershed, just before the } \\
\text { ocean; Upstream: Transitions } \\
\text { from low rolling hills with a } \\
\text { relatively unconfined valley to } \\
\text { slightly higher hills and more } \\
\text { narrow canyons; Watershed } \\
\text { does not go back much into } \\
\text { the high Santa Ana } \\
\text { Mountains, so not much deep } \\
\text { incised canyons }\end{array}$ \\
\hline $\begin{array}{l}\text { Dry Beaver } \\
\text { Creek near } \\
\text { Rimrock, AZ }\end{array}$ & 34.72863146 & -111.775708 & North-South & Compound & $\begin{array}{l}\text { Tropical/ } \\
\text { Subtropical } \\
\text { Steppe }\end{array}$ & Soft Rock & $\begin{array}{l}\text { Downstream: Tertiary basalt; } \\
\text { Upstream from gauge: } \\
\text { Pennsylvanian/Permian } \\
\text { sedimentary rocks; farther } \\
\text { upstream, more basalt }\end{array}$ & $\begin{array}{l}\text { Gauge is at the midpoint in } \\
\text { the watershed between plains } \\
\text { and a highly dissected plateau } \\
\text { with a canyon }\end{array}$ \\
\hline $\begin{array}{l}\text { Mojave River } \\
\text { near Afton, } \\
\text { CA }\end{array}$ & 35.03720565 & -116.3841887 & West-East & Compound & $\begin{array}{l}\text { Tropical/ } \\
\text { Subtropical } \\
\text { Desert }\end{array}$ & $\begin{array}{l}\text { Mixed } \\
\text { Soil }\end{array}$ & $\begin{array}{l}\text { Quaternary sedimentary } \\
\text { deposits and Tertiary and } \\
\text { Quaternary volcanic rocks }\end{array}$ & $\begin{array}{l}\text { Upland plateau with } \\
\text { surrounding hills }\end{array}$ \\
\hline $\begin{array}{l}\text { Santa Maria } \\
\text { River near } \\
\text { Bagdad, AZ }\end{array}$ & 34.30585401 & -113.3471441 & $\begin{array}{l}\text { North- } \\
\text { Southwest }\end{array}$ & Compound & $\begin{array}{l}\text { Tropical/ } \\
\text { Subtropical } \\
\text { Desert }\end{array}$ & Soft Rock & $\begin{array}{l}\text { Downstream for gauge: } \\
\text { Tertiary sedimentary rock with } \\
\text { some Tertiary volcanics; } \\
\text { Upstream: same as } \\
\text { downstream but also with } \\
\text { significant area of Proterozoic } \\
\text { granitic rocks }\end{array}$ & $\begin{array}{l}\text { Channel is at highest point of } \\
\text { a developed flood plain, still } \\
\text { surrounded by low hills }\end{array}$ \\
\hline $\begin{array}{l}\text { Susie Creek } \\
\text { at Carlin, NV }\end{array}$ & 40.72602928 & -116.0778547 & North-South & $\begin{array}{l}\text { Discontinuous } \\
\text { Ephemeral }\end{array}$ & $\begin{array}{l}\text { Temperate } \\
\text { Desert }\end{array}$ & Soft Rock & $\begin{array}{l}\text { Tuffaceous sedimentary rock, } \\
\text { with Tertiary volcanics above } \\
\text { gauge }\end{array}$ & $\begin{array}{l}\text { Channel is in dissected } \\
\text { intermontane plains }\end{array}$ \\
\hline
\end{tabular}




\section{Appendix B. Aerial Imagery and Discharge Events}

\begin{tabular}{|c|c|c|c|c|c|c|c|}
\hline Water body & $\begin{array}{c}\text { Date of } \\
\text { first photo }\end{array}$ & $\begin{array}{l}\text { Date of } \\
\text { second } \\
\text { photo }\end{array}$ & $\begin{array}{c}\text { Month and year } \\
\text { of discharge } \\
\text { event }\end{array}$ & $\begin{array}{c}\text { Size of event } \\
\text { (years) }\end{array}$ & $\begin{array}{l}\text { Discharge } \\
\text { event } \\
\text { category } \\
\text { (years) }\end{array}$ & $\begin{array}{l}\text { Years } \\
\text { between } \\
\text { photos }\end{array}$ & $\begin{array}{c}\text { Years between } \\
\text { event and second } \\
\text { photo }\end{array}$ \\
\hline Agua Fria & $4 / 30 / 97$ & $10 / 12 / 03$ & $3 / 98$ & 3.1 & $1-4$ & 6.5 & 5.5 \\
\hline Altar Wash & $6 / 19 / 96$ & $9 / 14 / 03$ & $7 / 99$ & 3.5 & $1-4$ & 7.25 & 4.25 \\
\hline Chinle Creek & $9 / 3 / 92$ & $10 / 14 / 97$ & $2 / 93$ & 8.6 & $4-10$ & 5.0 & 4.5 \\
\hline Cristianitos Creek & $6 / 1 / 94$ & $10 / 16 / 97$ & $3 / 95$ & 4.3 & $4-10$ & 3.25 & 2.5 \\
\hline Dry Beaver Creek & $6 / 17 / 97$ & 9/17/03 & 3/99 & 3.1 & $1-4$ & 6.25 & 4.5 \\
\hline Mojave River & $9 / 03$ & $9 / 05$ & $1 / 05$ & 18.7 & $10-25$ & 2.0 & 0.75 \\
\hline Santa Maria River & $9 / 26 / 92$ & $5 / 31 / 97$ & $2 / 93$ & 7.0 & $4-10$ & 4.5 & 4.25 \\
\hline Susie Creek & $6 / 10 / 94$ & $9 / 27 / 99$ & $3 / 97$ & 7.0 & $4-10$ & 5.25 & 2.5 \\
\hline
\end{tabular}




\section{Appendix C. Aerial Photos and Channel Morphological and Vegetation Delineation}



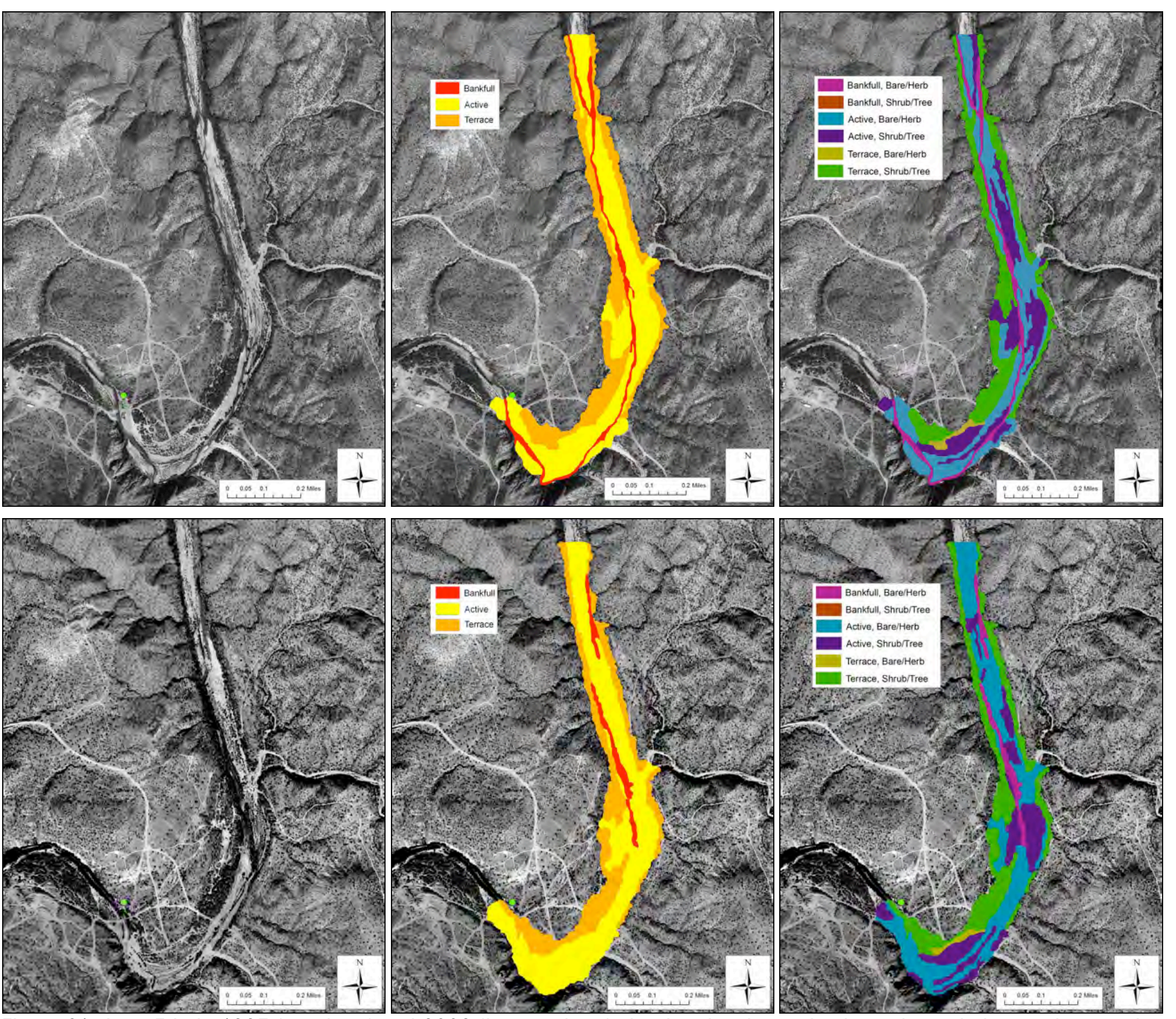

Figure C1. Agua Fria in 1997 (top three) and 2003 (bottom three) showing the change in channel morphology and vegetation. 

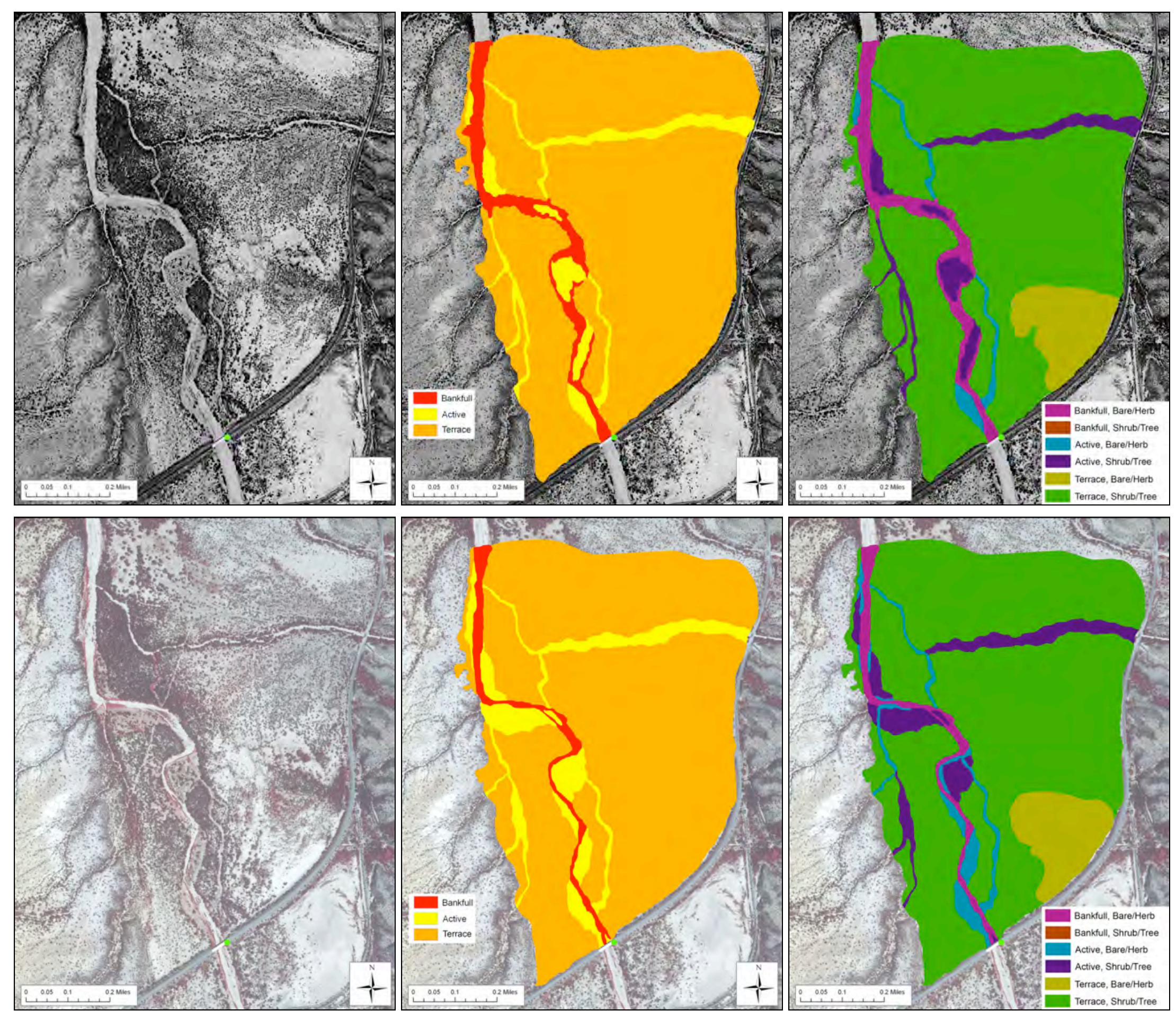

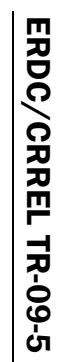

Figure C2. Altar Wash in 1996 (top three) and 2003 (bottom three) showing the change in channel morphology and vegetation. 

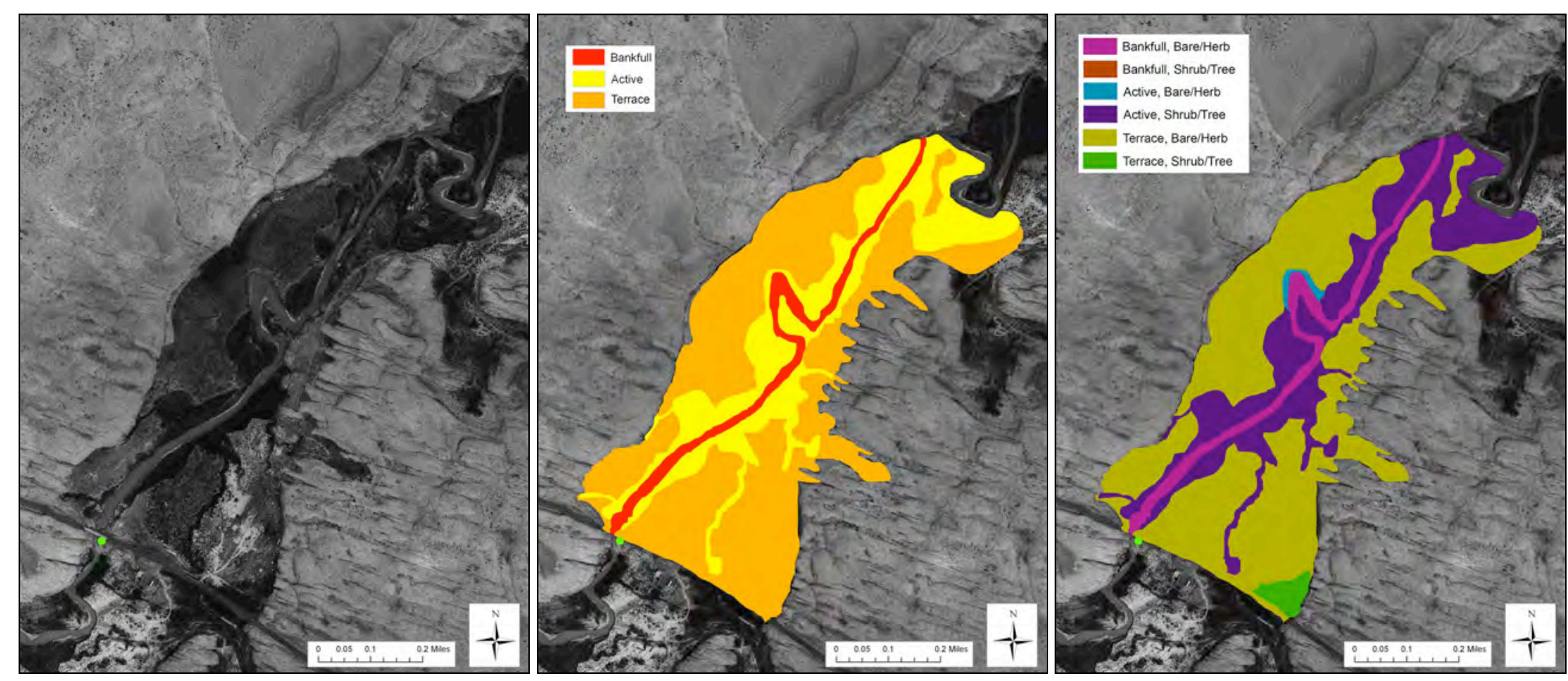

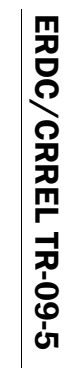

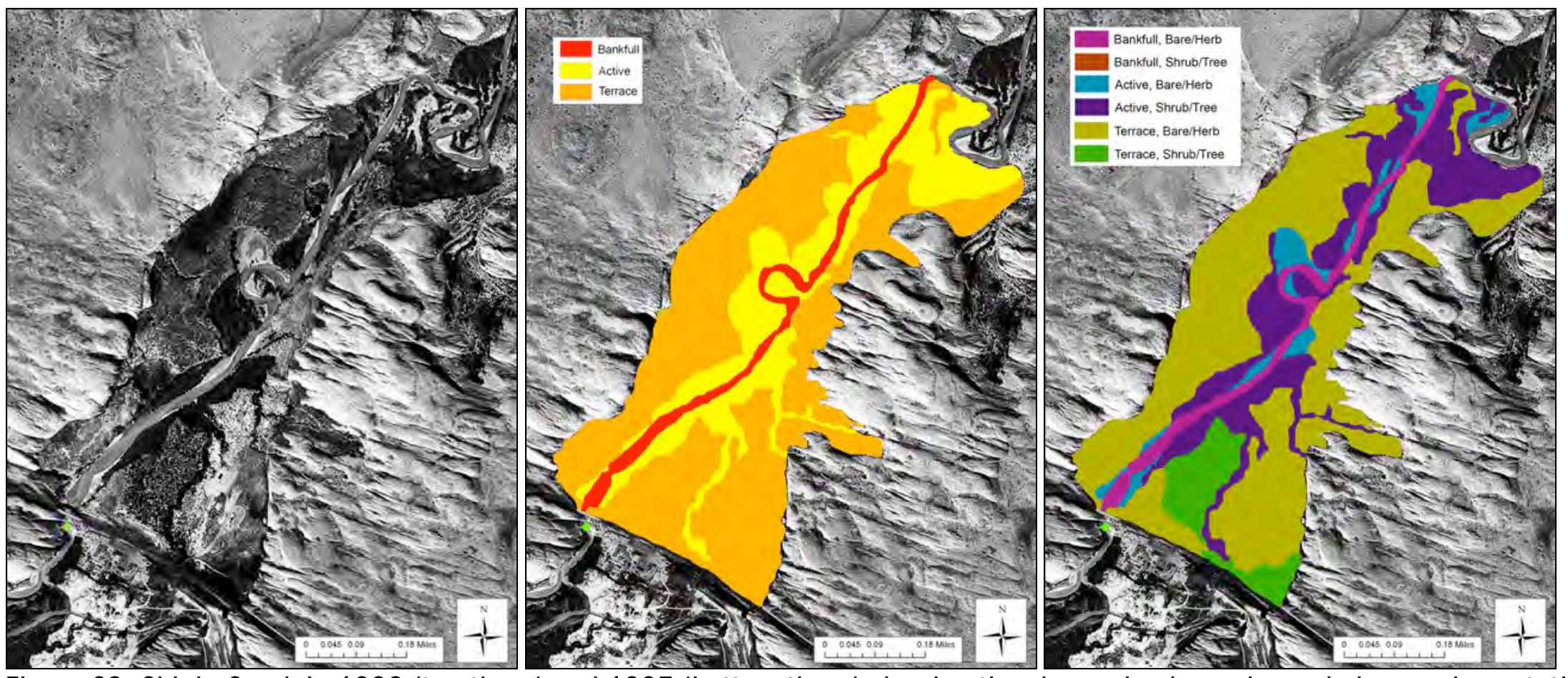




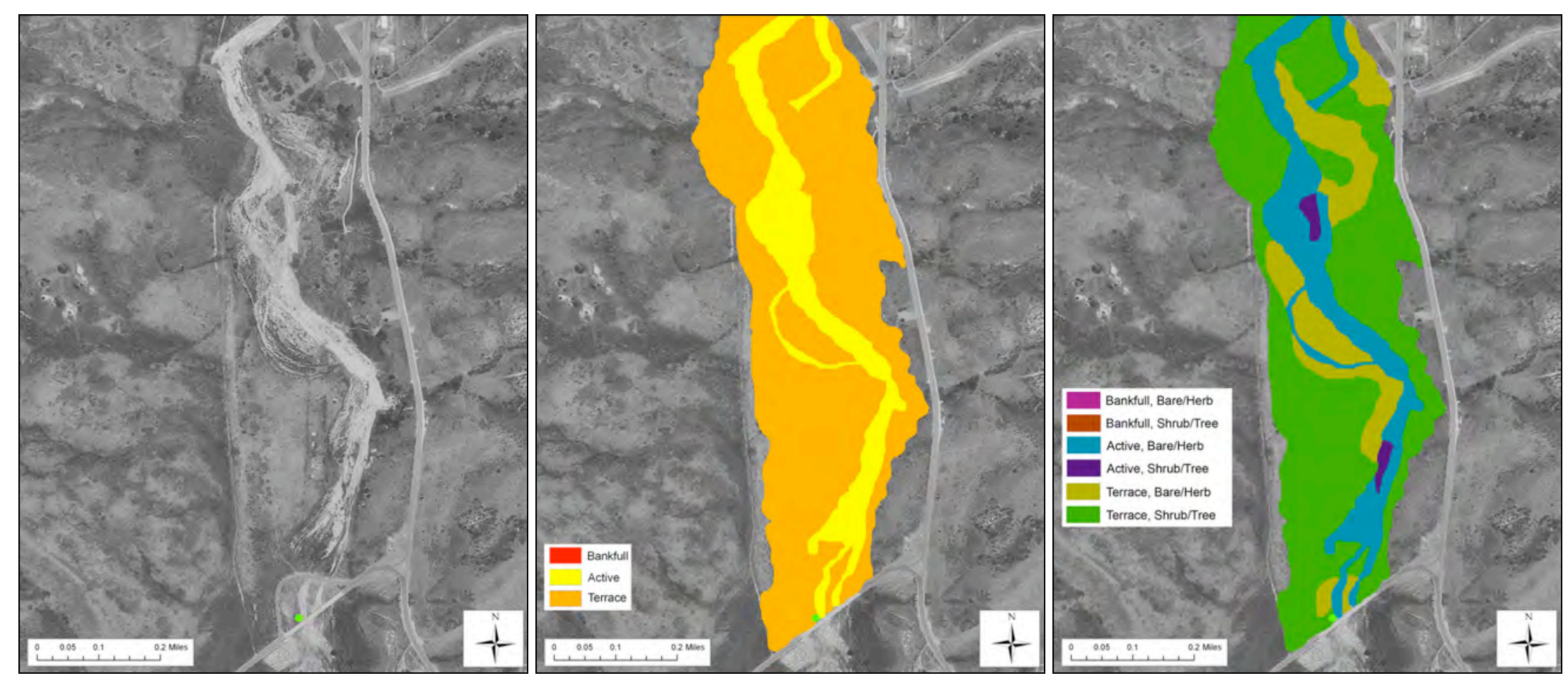

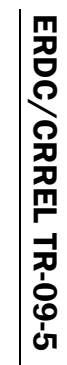

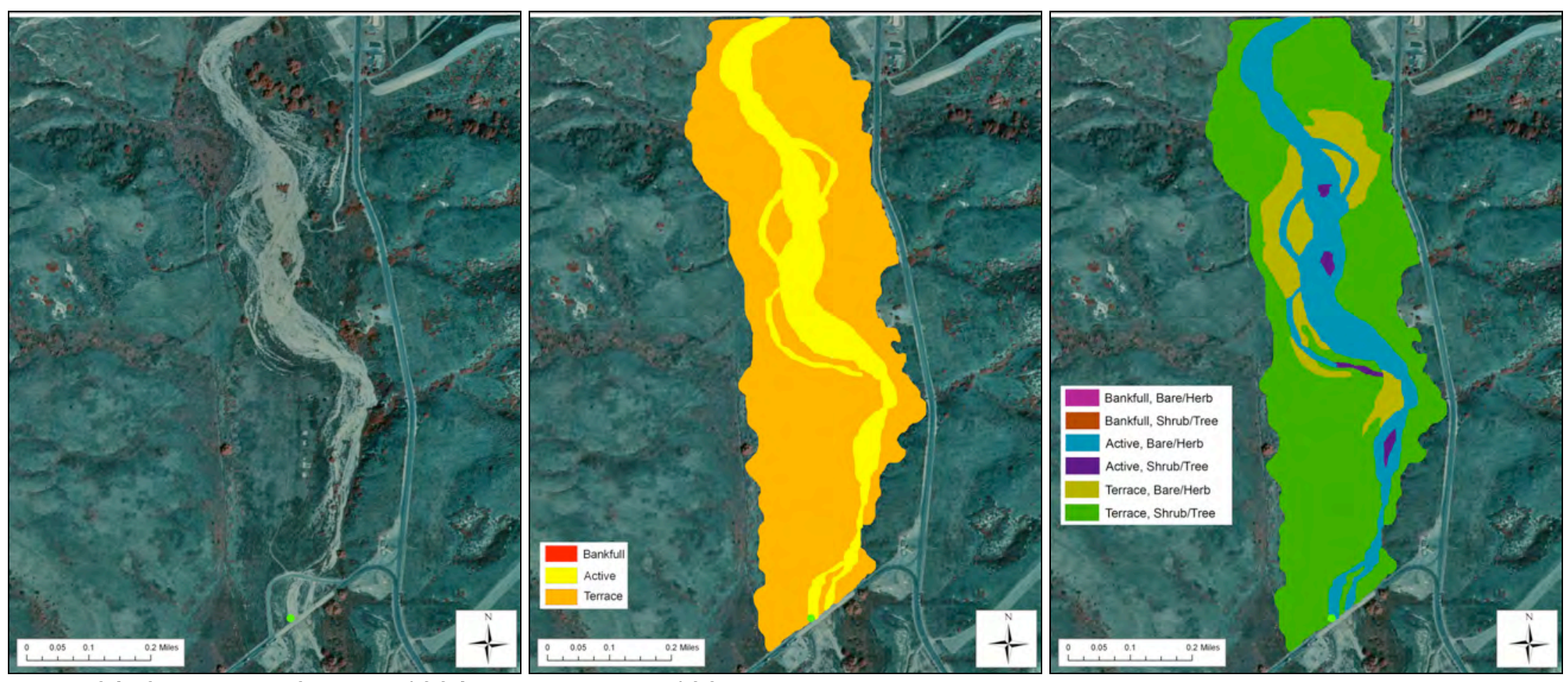

Figure C4. Cristianitos Creek in 1994 (top three) and 1997 (bottom three) showing the change in channel morphology and vegetation. 


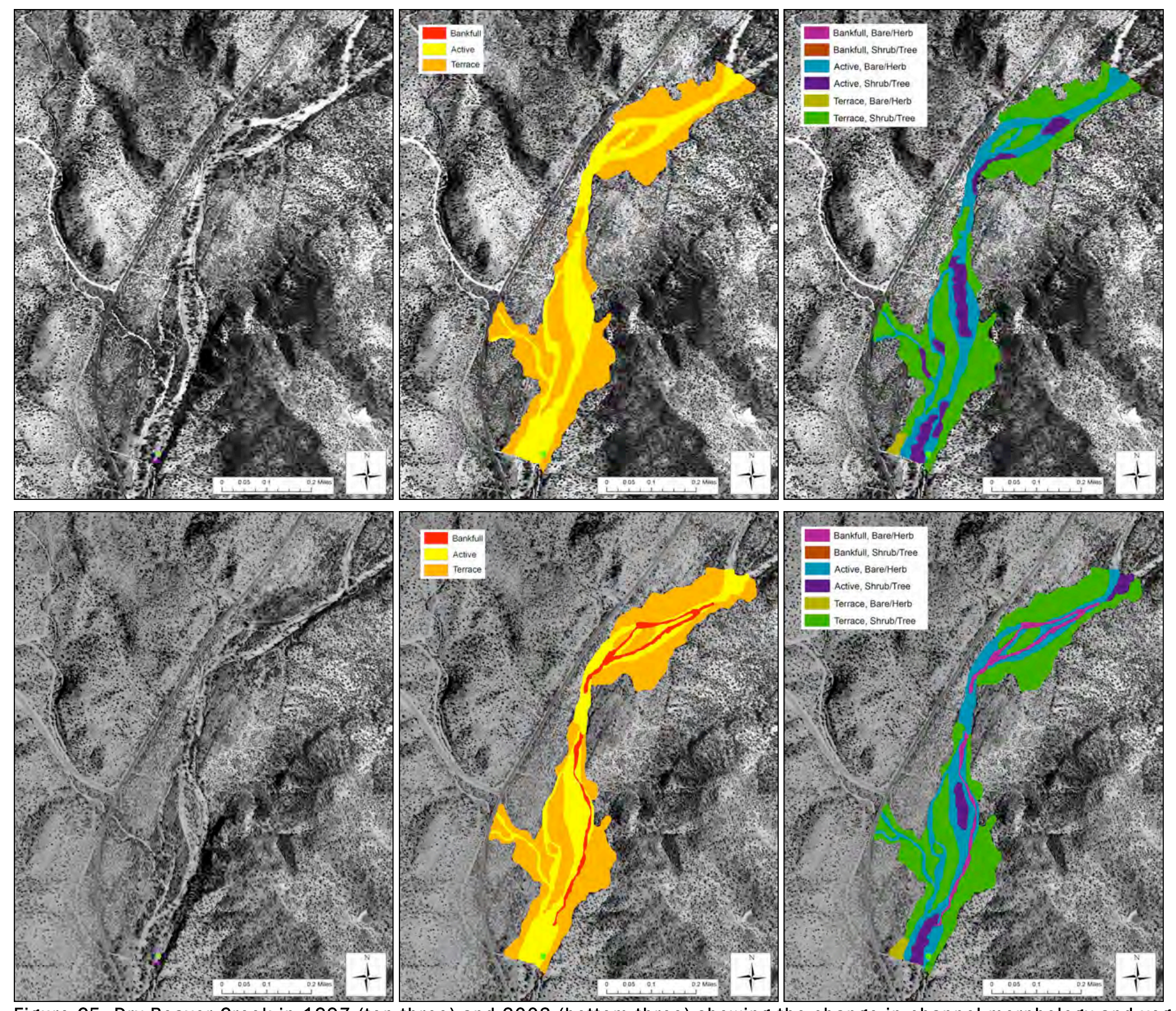



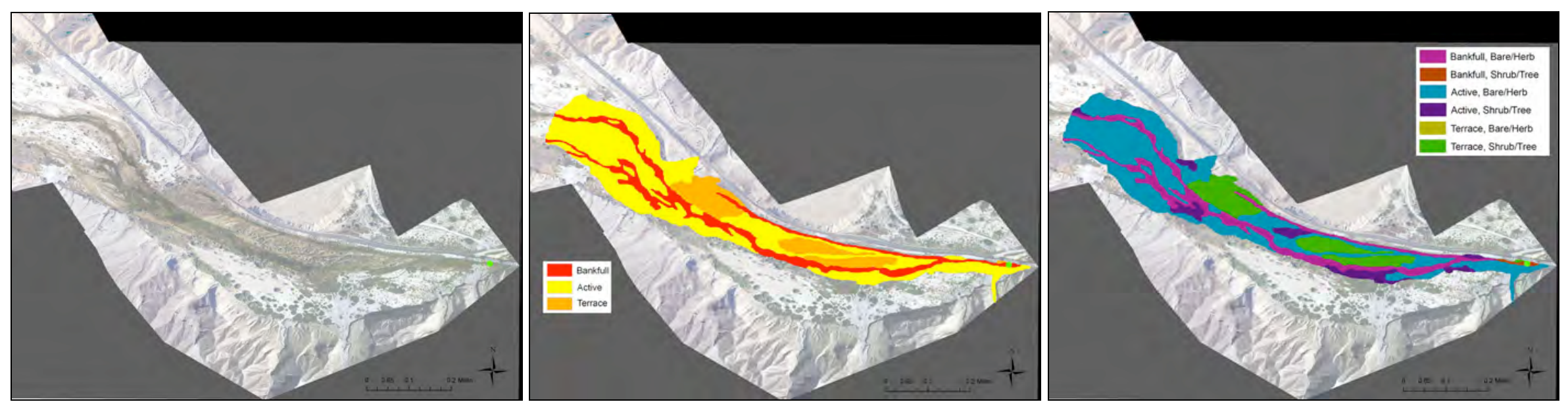

\begin{tabular}{|c|}
\hline 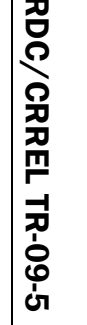 \\
\hline
\end{tabular}
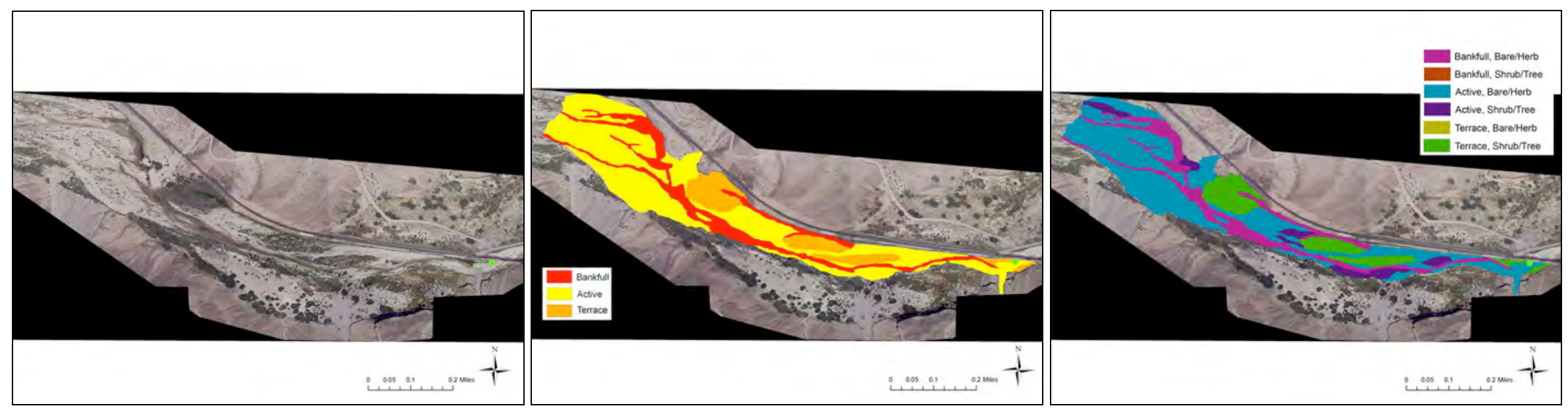

Figure C6. Mojave River in 2003 (top three) and 2005 (bottom three) showing the change in channel morphology and vegetation. 

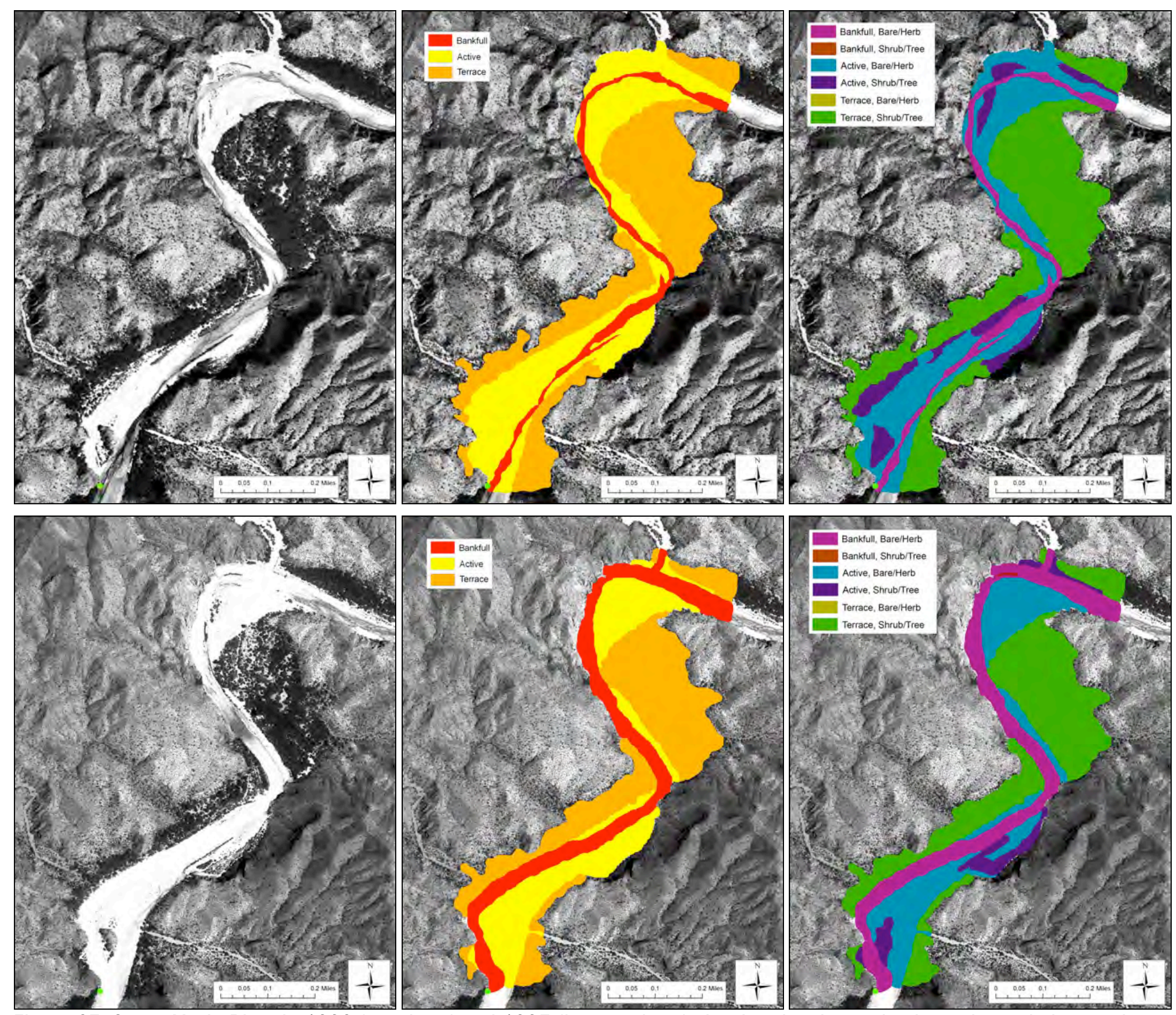

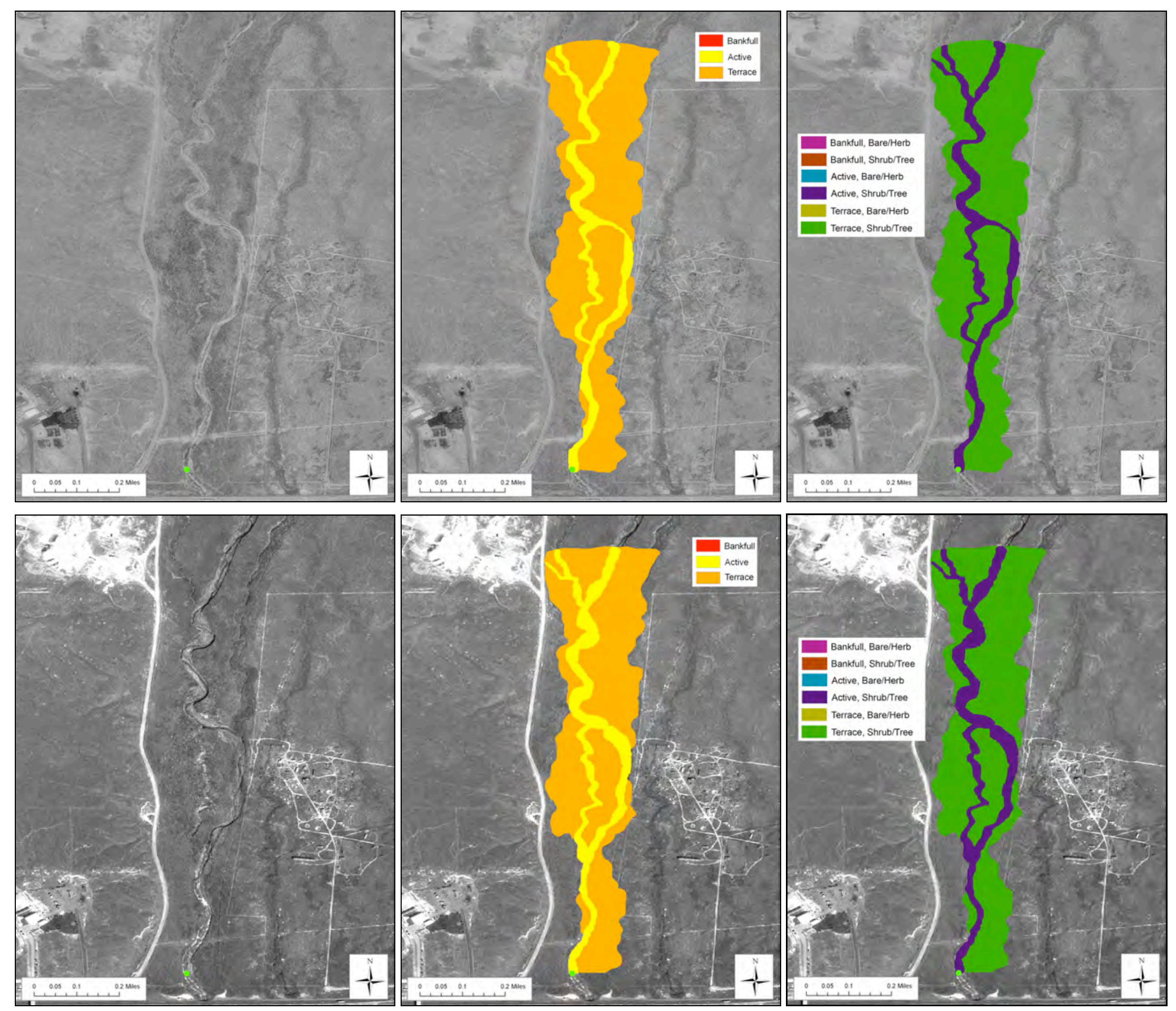

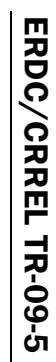

Figure C8. Susie Creek in 1994 (top three) and 1999 (bottom three) showing the change in channel morphology and vegetation. 


\section{Appendix D. Data Extracted from Delineations}

Table D1. Data for Agua Fria (3.1-year flood).

\begin{tabular}{|l|c|c|c|c|}
\hline \multirow{2}{*}{} & \multicolumn{2}{|c|}{1997} & \multicolumn{2}{c|}{2003} \\
\cline { 2 - 5 } & Area $\left(\mathrm{m}^{2}\right)$ & $\%$ of Total & Area $\left(\mathrm{m}^{2}\right)$ & \% of Total \\
\hline Bankfull & 40,036 & 10.1 & 22,484 & 5.5 \\
\hline Active & 218,184 & 55.1 & 243,672 & 60.2 \\
\hline Terrace & 137,861 & 34.8 & 139,801 & 34.4 \\
\hline Total & 396,081 & 100 & 405,957 & 100.1 \\
\hline & & & & \\
\hline Bankfull-Bare/Herb & 40,036 & 10.1 & 22,484 & 5.5 \\
\hline Bankfull-Shrub/Tree & 0 & 0 & 0 & 0 \\
\hline Active-Bare/Herb & 133,259 & 33.6 & 154,432 & 38.0 \\
\hline Active-Shrub/Tree & 84,925 & 21.4 & 89,240 & 22.0 \\
\hline Terrace-Bare/Herb & 5,816 & 1.5 & 5,038 & 1.2 \\
\hline Terrace-Shrub/Tree & 132,045 & 33.3 & 134,763 & 33.2 \\
\hline Total & 396,081 & 99.9 & 405,957 & 99.9 \\
\hline
\end{tabular}

Table D2. Data for Altar Wash (3.5-year flood).

\begin{tabular}{|l|c|c|r|c|}
\hline \multirow{2}{*}{} & \multicolumn{2}{|c|}{1996} & \multicolumn{2}{c|}{2003} \\
\cline { 2 - 5 } & Area $\left(\mathrm{m}^{2}\right)$ & $\%$ of Total & Area $\left(\mathrm{m}^{2}\right)$ & \% of Total \\
\hline Bankfull & 78,531 & 5.7 & 46,273 & 3.4 \\
\hline Active & 108,693 & 7.8 & 153,465 & 11.1 \\
\hline Terrace & $1,197,934$ & 86.5 & $1,177,784$ & 85.5 \\
\hline Total & $1,385,158$ & 100 & $1,377,522$ & 100 \\
\hline & & & & \\
\hline Bankfull-Bare/Herb & 78,531 & 5.7 & 46,273 & 3.4 \\
\hline Bankfull-Shrub/Tree & 0 & 0 & 0 & 0 \\
\hline Active-Bare/Herb & 27,862 & 2.0 & 57,074 & 4.1 \\
\hline Active-Shrub/Tree & 80,831 & 5.8 & 96,390 & 7.0 \\
\hline Terrace-Bare/Herb & 100,612 & 7.3 & 101,398 & 7.4 \\
\hline Terrace-Shrub/Tree & $1,097,322$ & 79.2 & $1,076,386$ & 78.1 \\
\hline Total & $1,385,158$ & 99.9 & $1,377,521$ & 100 \\
\hline
\end{tabular}


Table D3. Data for Chinle Creek (8.6-year flood).

\begin{tabular}{|l|c|c|c|c|}
\hline \multirow{2}{*}{} & \multicolumn{2}{|c|}{1992} & \multicolumn{2}{c|}{1997} \\
\cline { 2 - 5 } & Area $\left(\mathrm{m}^{2}\right)$ & $\%$ of Total & Area $\left(\mathrm{m}^{2}\right)$ & \% of Total \\
\hline Bankfull & 50,329 & 6.4 & 46,806 & 5.9 \\
\hline Active & 232,373 & 29.5 & 233,880 & 29.4 \\
\hline Terrace & 505,251 & 64.1 & 513,567 & 64.7 \\
\hline Total & 787,953 & 100 & 794,253 & 100 \\
\hline & & & & \\
\hline Bankfull-Bare/Herb & 50,329 & 6.4 & 46,806 & 5.9 \\
\hline Bankfull-Shrub/Tree & 0 & 0 & 0 & 0 \\
\hline Active-Bare/Herb & 4,574 & 0.6 & 41,887 & 5.2 \\
\hline Active-Shrub/Tree & 227,798 & 28.9 & 191,993 & 24.2 \\
\hline Terrace-Bare/Herb & 491,890 & 62.4 & 453,360 & 57.1 \\
\hline Terrace-Shrub/Tree & 13,361 & 1.7 & 60,206 & 7.6 \\
\hline Total & 787,952 & 100 & 794,252 & 100 \\
\hline
\end{tabular}

Table D4. Data for Cristianitos Creek (4.3-year flood).

\begin{tabular}{|l|c|c|c|c|}
\hline \multirow{2}{*}{} & \multicolumn{2}{|c|}{1994} & \multicolumn{2}{c|}{1997} \\
\cline { 2 - 5 } & Area $\left(\mathrm{m}^{2}\right)$ & $\%$ of Total & Area $\left(\mathrm{m}^{2}\right)$ & \% of Total \\
\hline Bankfull & 0 & 0 & 0 & 0 \\
\hline Active & 109,841 & 22.2 & 104,513 & 21.3 \\
\hline Terrace & 384,010 & 77.8 & 385,602 & 78.7 \\
\hline Total & 493,851 & 100 & 490,115 & 100 \\
\hline & & & & 0 \\
\hline Bankfull-Bare/Herb & 0 & 0 & 0 & 0 \\
\hline Bankfull-Shrub/Tree & 0 & 0 & 0 & 20.4 \\
\hline Active-Bare/Herb & 103,763 & 21.0 & 99,869 & 1.0 \\
\hline Active-Shrub/Tree & 6,078 & 1.2 & 4,644 & 11.0 \\
\hline Terrace-Bare/Herb & 83,897 & 17.0 & 55,073 & 67.4 \\
\hline Terrace-Shrub/Tree & 300,112 & 60.8 & 330,529 & 99.8 \\
\hline Total & 493,850 & 100 & 490,115 & \\
\hline
\end{tabular}


Table D5. Data for Dry Beaver Creek (3.1-year flood).

\begin{tabular}{|l|c|c|c|c|}
\hline \multirow{2}{*}{} & \multicolumn{2}{|c|}{1997} & \multicolumn{2}{c|}{2003} \\
\cline { 2 - 5 } & Area $\left(\mathrm{m}^{2}\right)$ & $\%$ of Total & Area $\left(\mathrm{m}^{2}\right)$ & $\%$ of Total \\
\hline Bankfull & 0 & 0 & 18,938 & 6.5 \\
\hline Active & 114,061 & 39.5 & 96,769 & 33.0 \\
\hline Terrace & 174,763 & 60.5 & 177,198 & 60.5 \\
\hline Total & 288,824 & 100 & 292,905 & 100 \\
\hline & & & & \\
\hline Bankfull-Bare/Herb & 0 & 0 & 18,938 & 6.5 \\
\hline Bankfull-Shrub/Tree & 0 & 0 & 0 & 0 \\
\hline Active-Bare/Herb & 80,973 & 28.0 & 79,125 & 27.0 \\
\hline Active-Shrub/Tree & 33,088 & 11.5 & 17,644 & 6.0 \\
\hline Terrace-Bare/Herb & 3,006 & 1.0 & 3,301 & 1.1 \\
\hline Terrace-Shrub/Tree & 171,756 & 59.5 & 173,897 & 59.4 \\
\hline Total & 288,823 & 100 & 292,905 & 100 \\
\hline
\end{tabular}

Table D6. Data for Mojave River (18.7-year flood).

\begin{tabular}{|l|c|c|c|c|}
\hline \multirow{2}{*}{} & \multicolumn{2}{|c|}{2003} & \multicolumn{2}{c|}{2005} \\
\cline { 2 - 5 } & Area $\left(\mathrm{m}^{2}\right)$ & $\%$ of Total & Area $\left(\mathrm{m}^{2}\right)$ & \% of Total \\
\hline Bankfull & 52,926 & 21.5 & 52,216 & 21.4 \\
\hline Active & 153,097 & 62.2 & 154,149 & 63.3 \\
\hline Terrace & 39,979 & 16.2 & 37,228 & 15.3 \\
\hline Total & 246,002 & 99.9 & 243,593 & 100 \\
\hline & & & & 21.4 \\
\hline Bankfull-Bare/Herb & 51,465 & 20.9 & 52,216 & 0 \\
\hline Bankfull-Shrub/Tree & 1,461 & 0.6 & 0 & 56.4 \\
\hline Active-Bare/Herb & 134,917 & 54.8 & 137,357 & 6.9 \\
\hline Active-Shrub/Tree & 18,180 & 7.4 & 16,792 & 0 \\
\hline Terrace-Bare/Herb & 0 & 0 & 0 & 15.3 \\
\hline Terrace-Shrub/Tree & 39,979 & 16.2 & 37,228 & 100 \\
\hline Total & 246,002 & 99.9 & 243,593 & \\
\hline
\end{tabular}


Table D7. Data for Santa Maria River (7.0-year flood).

\begin{tabular}{|l|c|c|c|c|}
\hline \multirow{2}{*}{} & \multicolumn{2}{|c|}{1992} & \multicolumn{2}{c|}{1997} \\
\cline { 2 - 5 } & Area $\left(\mathrm{m}^{2}\right)$ & $\%$ of Total & Area $\left(\mathrm{m}^{2}\right)$ & \% of Total \\
\hline Bankfull & 49,591 & 9.4 & 116,811 & 23.8 \\
\hline Active & 222,002 & 41.9 & 150,773 & 30.7 \\
\hline Terrace & 257,963 & 48.7 & 223,503 & 45.5 \\
\hline & 529,556 & 100 & 491,087 & 100 \\
\hline Bankfull-Bare/Herb & 49,591 & 9.4 & 116,233 & 23.7 \\
\hline Bankfull-Shrub/Tree & 0 & 0 & 578 & 0.1 \\
\hline Active-Bare/Herb & 171,218 & 32.3 & 122,274 & 24.9 \\
\hline Active-Shrub/Tree & 50,784 & 9.6 & 28,499 & 5.8 \\
\hline Terrace-Bare/Herb & 0 & 0 & 0 & 0 \\
\hline Terrace-Shrub/Tree & 257,963 & 48.7 & 223,503 & 45.5 \\
\hline Total & 529,556 & 100 & 491,087 & 100 \\
\hline
\end{tabular}

Table D8. Data for Susie Creek (7.0-year flood).

\begin{tabular}{|l|c|c|c|c|}
\hline \multirow{2}{*}{} & \multicolumn{2}{|c|}{1994} & \multicolumn{2}{c|}{1999} \\
\cline { 2 - 5 } & Area $\left(\mathrm{m}^{2}\right)$ & $\%$ of Total & Area $\left(\mathrm{m}^{2}\right)$ & \% of Total \\
\hline Bankfull & 0 & 0 & 0 & 0 \\
\hline Active & 60,627 & 19.1 & 69,927 & 22.3 \\
\hline Terrace & 256,129 & 80.7 & 243,011 & 77.6 \\
\hline Total & 316,756 & 99.8 & 312,938 & 99.9 \\
\hline & & & & \\
\hline Bankfull-Bare/Herb & 0 & 0 & 0 & 0 \\
\hline Bankfull-Shrub/Tree & 0 & 0 & 0 & 0 \\
\hline Active-Bare/Herb & 0 & 0 & 0 & 0 \\
\hline Active-Shrub/Tree & 60,627 & 19.1 & 69,927 & 22.3 \\
\hline Terrace-Bare/Herb & 0 & 0 & 0 & 0 \\
\hline Terrace-Shrub/Tree & 256,129 & 80.7 & 243,011 & 77.6 \\
\hline Total & 316,756 & 99.8 & 312,938 & 99.9 \\
\hline
\end{tabular}




\section{Appendix E: Photos Showing Zone Boundaries}

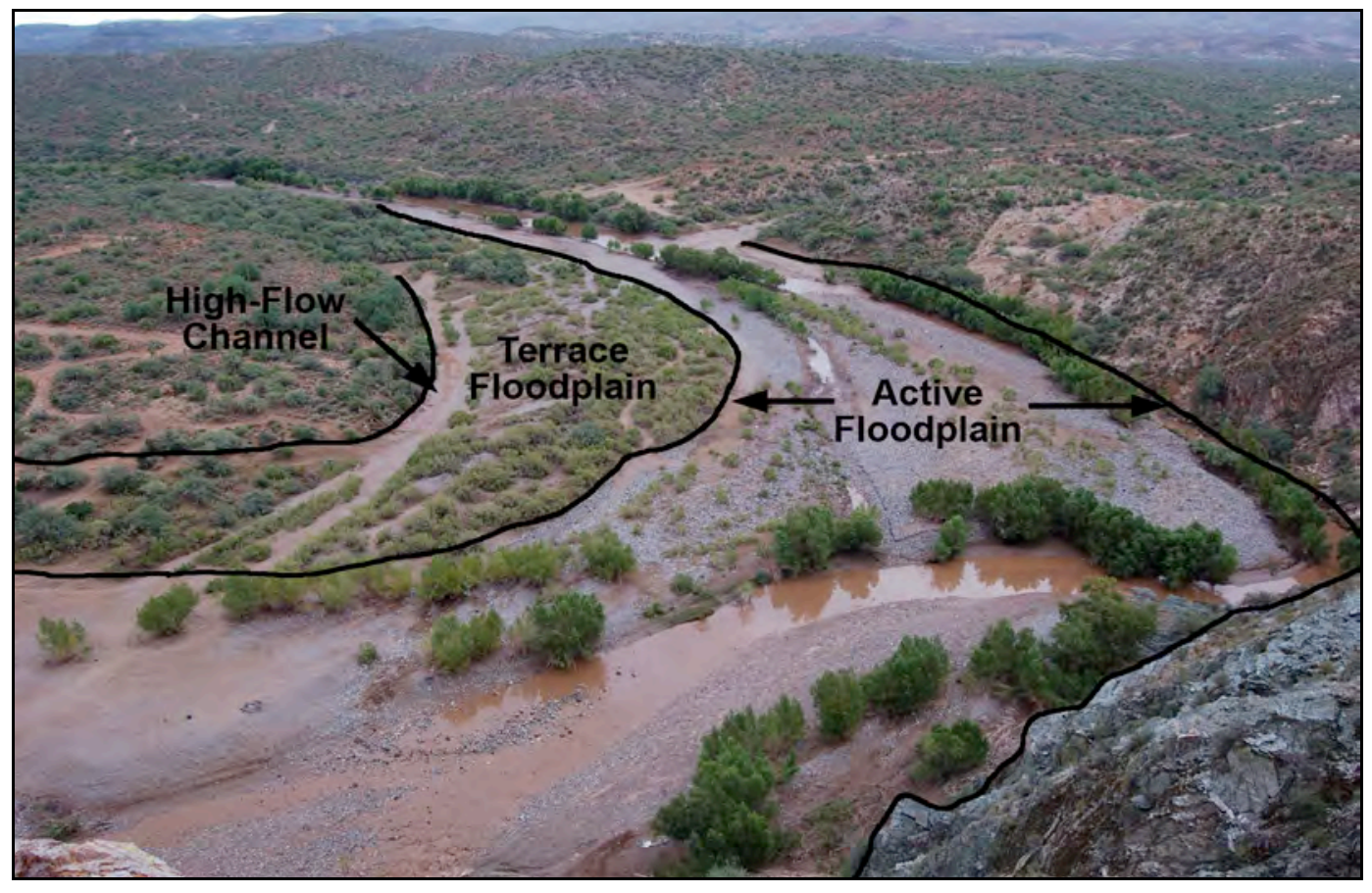

Figure E1. Agua Fria.

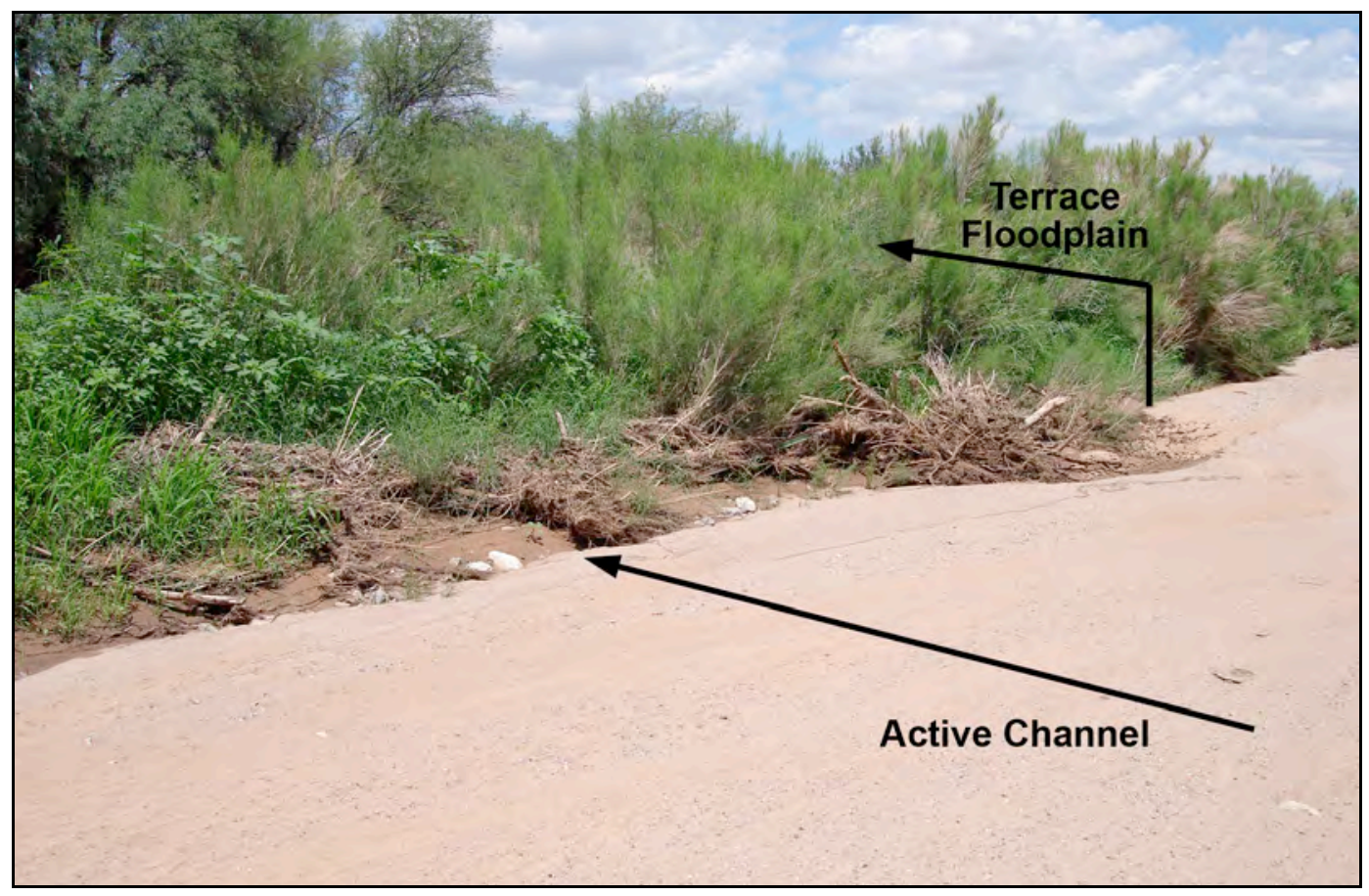

Figure E2. Drift at boundary of active channel, Altar Wash. 


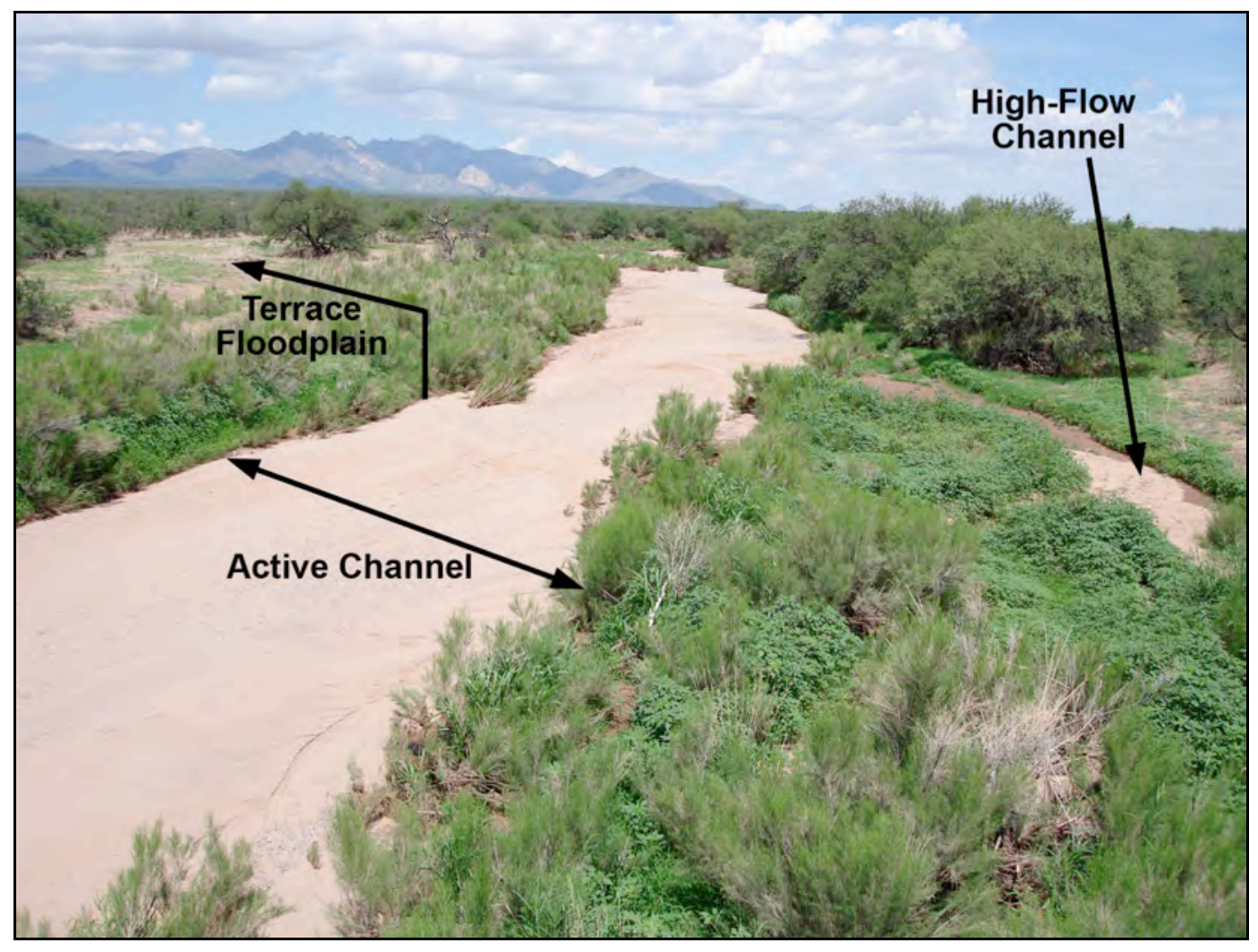

Figure E3. Altar Wash.

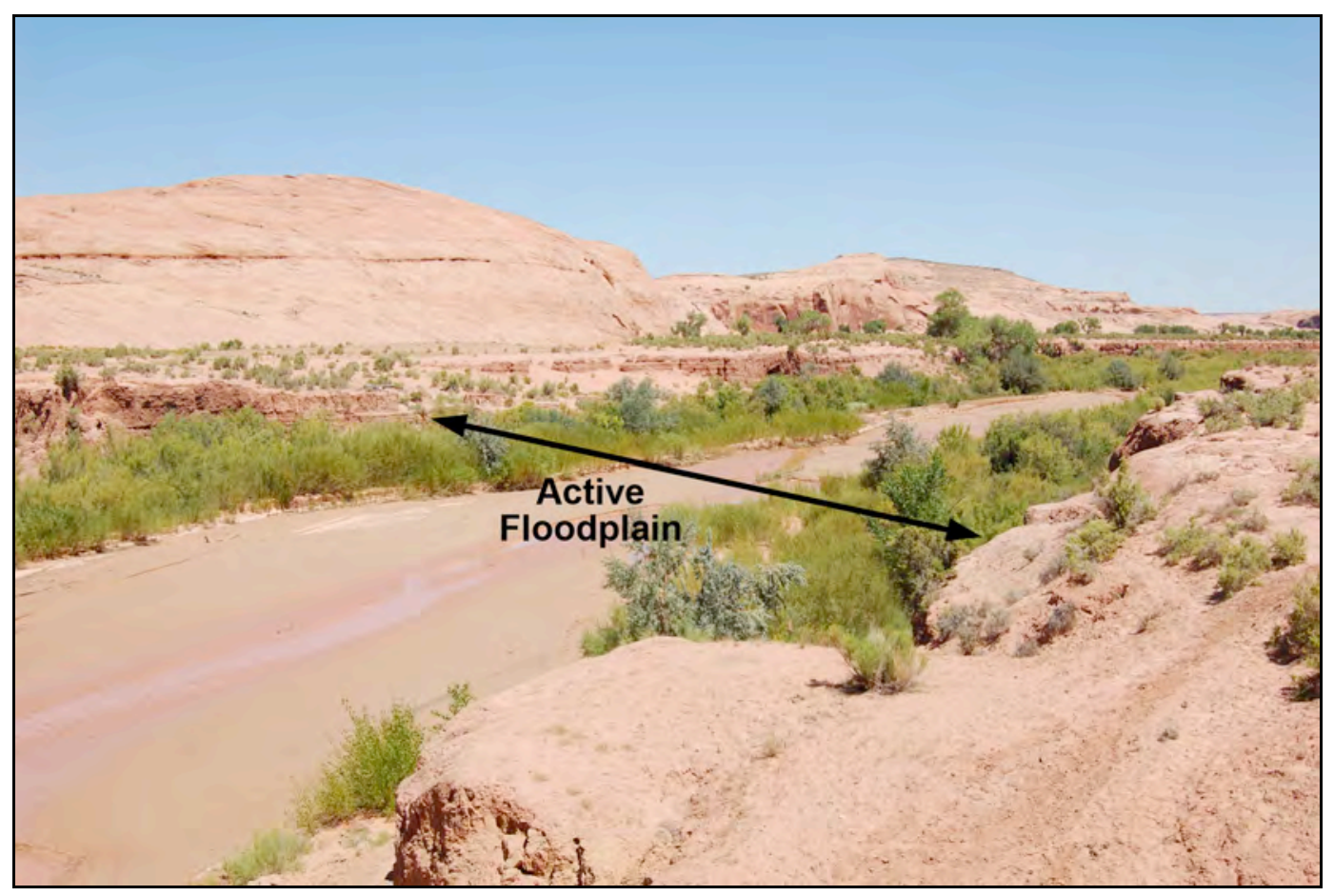

Figure E4. Active floodplain at Chinle Creek. 


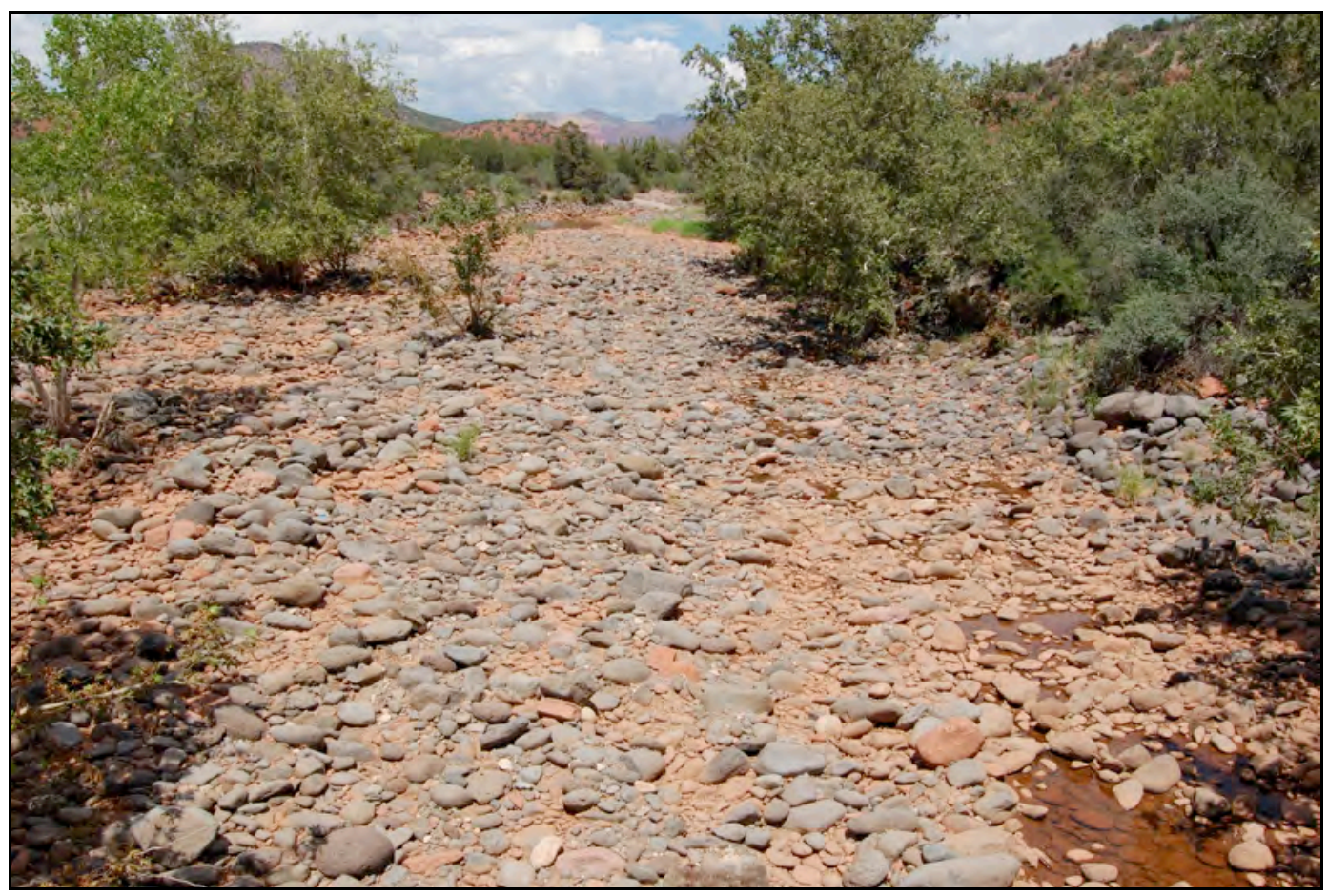

Figure E5. Active floodplain at Dry Beaver Creek.

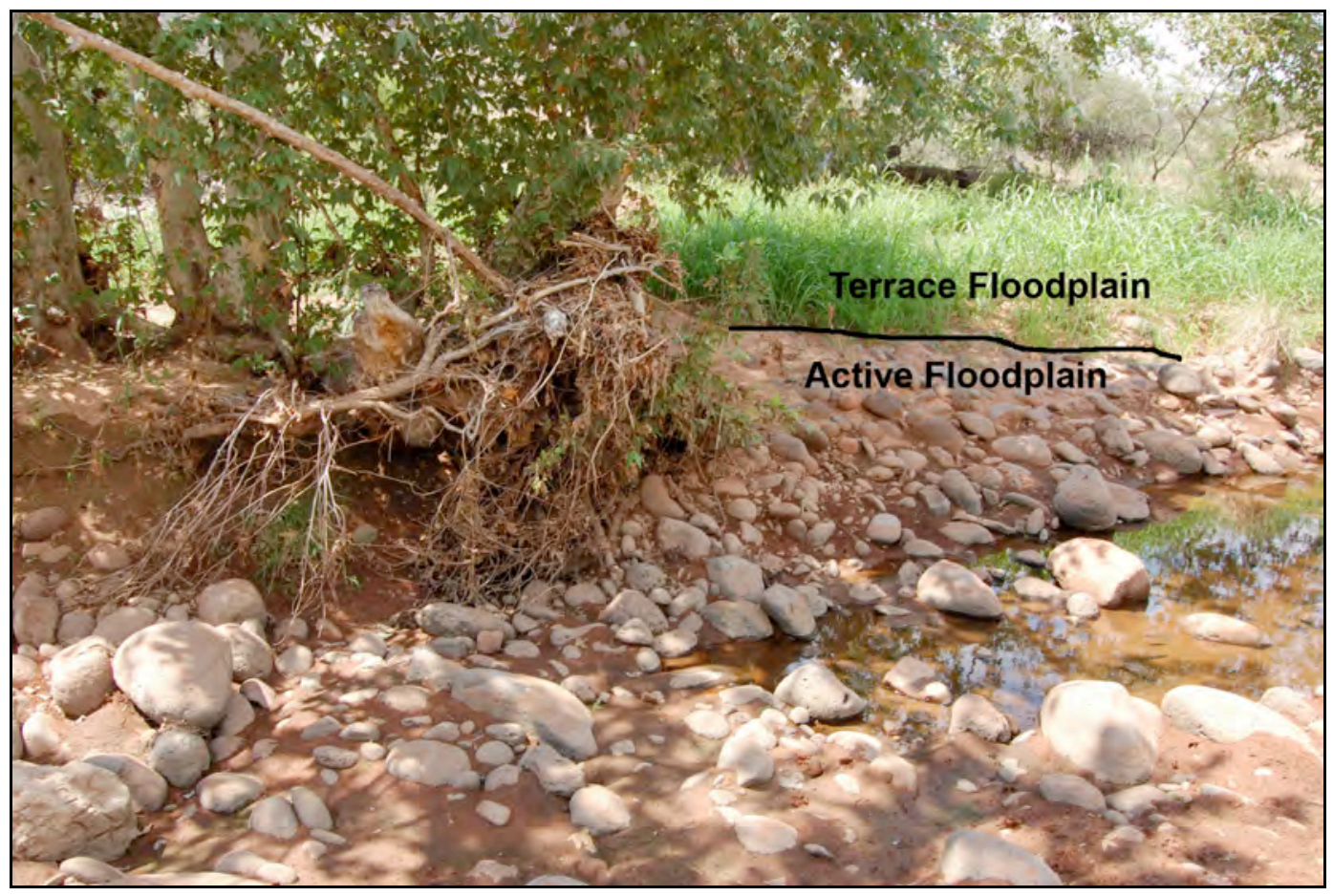

Figure E6. Boundary between the terrace floodplain and the active floodplain at Dry Beaver Creek. 


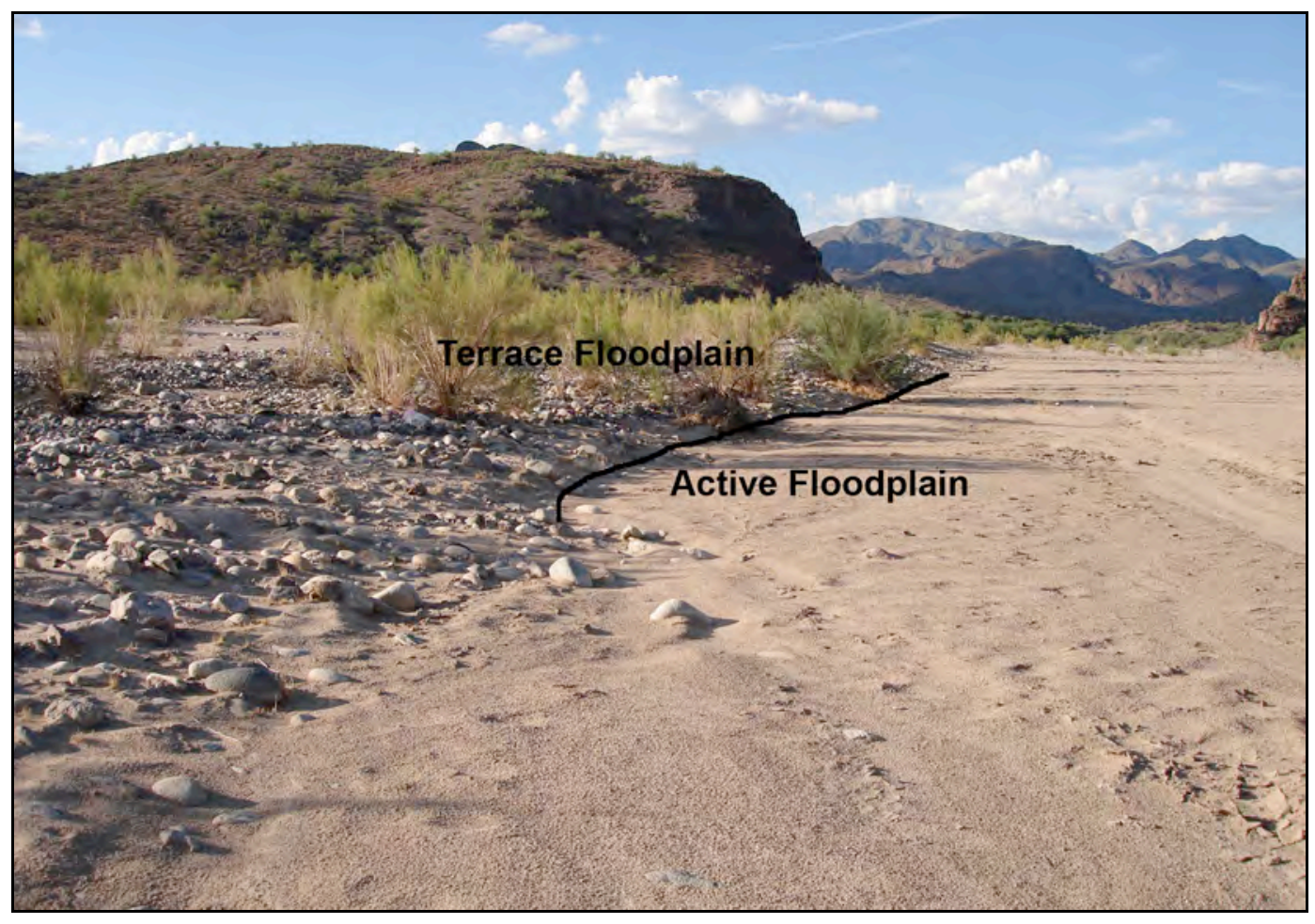

Figure E7. Boundary between the terrace floodplain and the active floodplain at Santa Maria Creek.

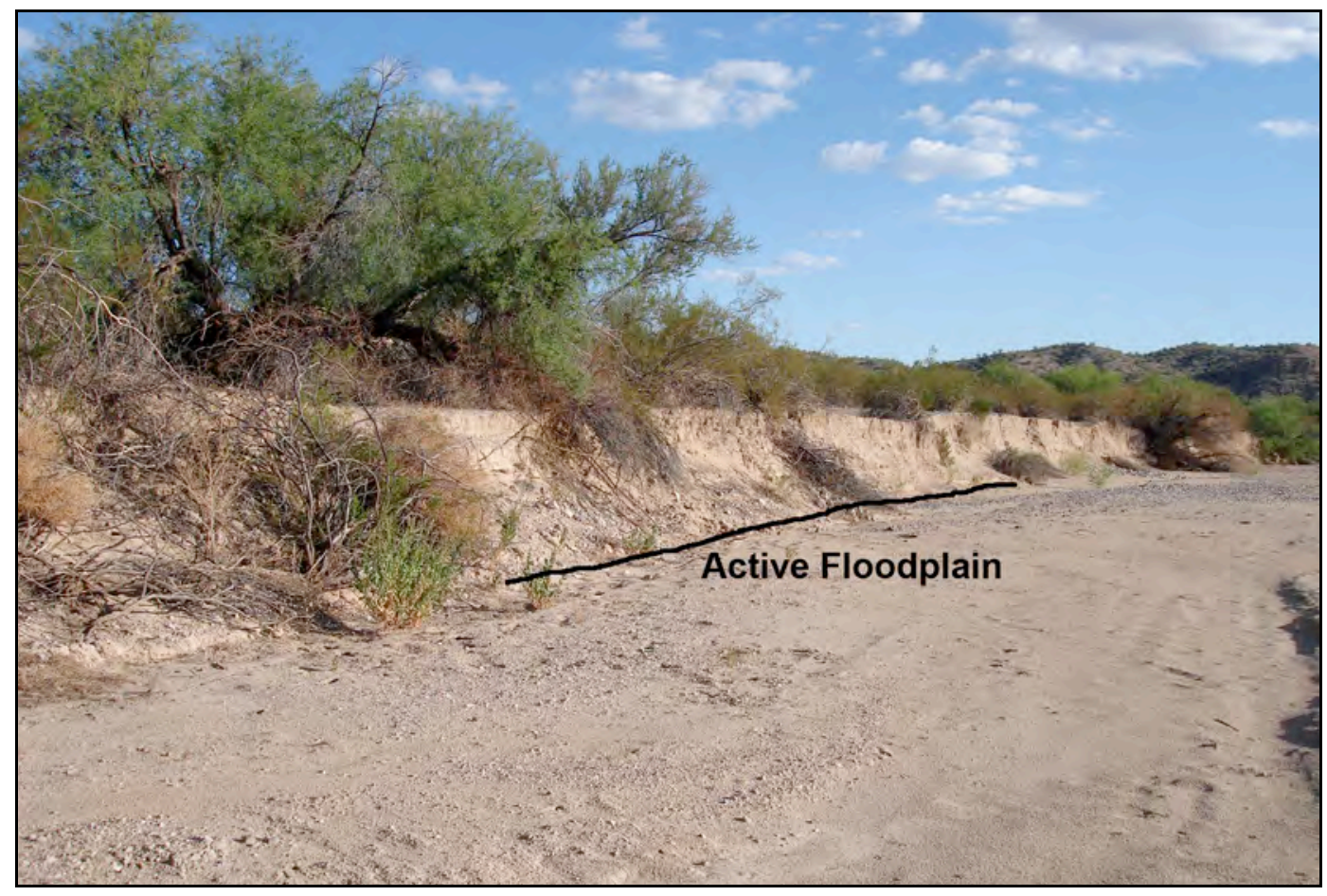

Figure E8. Active floodplain at Santa Maria Creek. 


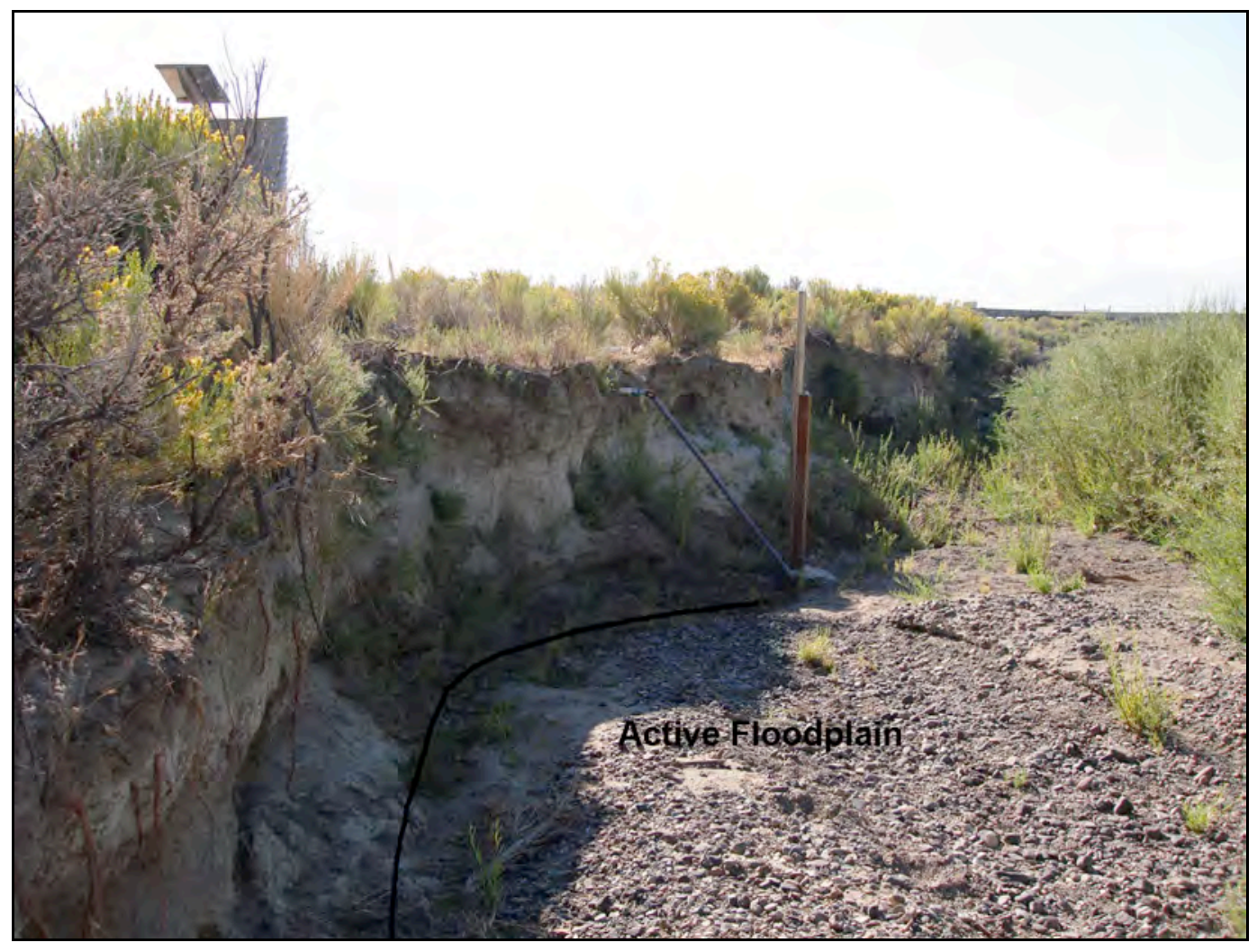

Figure E9. Active floodplain at the Susie Creek gauge.

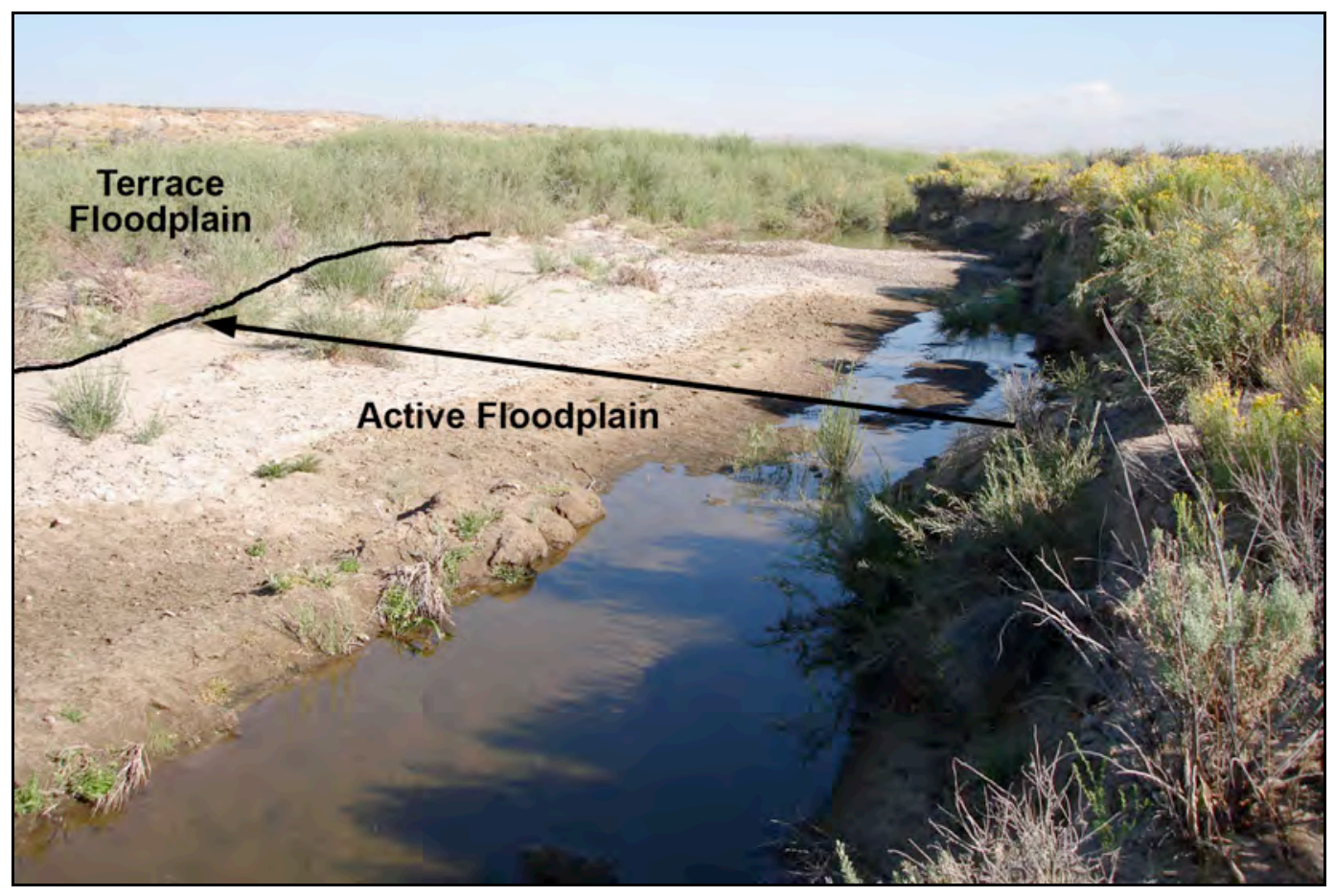

Figure E10. Boundary between the terrace floodplain and the active floodplain at Susie Creek. 


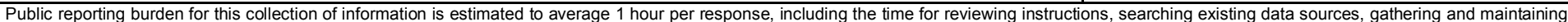

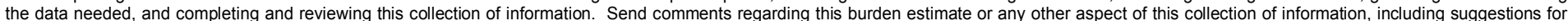

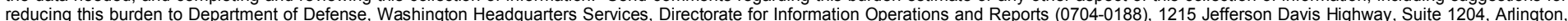

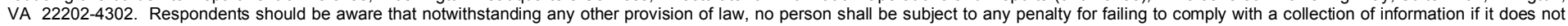
display a currently valid OMB control number. PLEASE DO NOT RETURN YOUR FORM TO THE ABOVE ADDRESS.
1. REPORT DATE (DD-MM-YYYY) 2. REPORT TYPE
May 2009
Technical Report

\section{TITLE AND SUBTITLE}

Vegetation and Channel Morphology Responses to Ordinary High Water

Discharge Events in Arid West Stream Channels

\section{AUTHOR(S)}

Robert Lichvar, David Cate, Corinna Photos, Lindsey Dixon, Bruce Allen, and Joel Byersdorfer

\section{DATES COVERED (From - To)}

5a. CONTRACT NUMBER

5b. GRANT NUMBER

5c. PROGRAM ELEMENT NUMBER

5d. PROJECT NUMBER

5e. TASK NUMBER

5f. WORK UNIT NUMBER

8. PERFORMING ORGANIZATION REPORT NUMBER

ERDC/CRREL TR-09-5

U.S. Army Engineer Research and Development Center Cold Regions Research and Engineering Laboratory 72 Lyme Road

Hanover, NH 03755-1290

9. SPONSORING / MONITORING AGENCY NAME(S) AND ADDRESS(ES)

10. SPONSOR/MONITOR'S ACRONYM(S)

11. SPONSOR/MONITOR'S REPORT $\operatorname{NUMBER}(\mathbf{S})$

\section{DISTRIBUTION / AVAILABILITY STATEMENT}

Approved for public release; distribution is unlimited.

Available from NTIS, Springfield, Virginia 22161.

\section{SUPPLEMENTARY NOTES}

\section{ABSTRACT}

"Waters of the United States" (WoUS) are regulated by the U.S. Army Corps of Engineers under Section 404 of the Clean Water Act (33 U.S.C. 1344). The Corps lateral jurisdictional extent in Arid West stream channels is the upper level of the ordinary high water (OHW). The channel shape, fluvial textures, and vegetation patterns of these arid stream channels are heavily influenced by short-term, high-intensity or "flashy" events, which create distinctive physical features and vegetation responses. To determine vegetation and channel morphology responses, sequential aerial photos and stream gauge data for eight ephemeral and intermittent stream channels in the Arid West were analyzed. The observed patterns associated with various discharge event levels are consistent with the Corps OHW delineation manual. The use of remote sensing resources provides another critical support tool for delineating the extent of the OHW in Arid West stream channels.

\section{SUBJECT TERMS}

Arid West stream channels

Channel morphology

16. SECURITY CLASSIFICATION OF:

$$
\text { a. REPORT }
$$$$
\mathrm{U}
$$

\section{Ordinary High Water}

Waters of the U.S.$$
\text { a. }
$$

\begin{tabular}{|c|c} 
b. ABSTRACT \\
$U$
\end{tabular}

\begin{tabular}{|c|c|}
\hline 17. LIMITATION & $\begin{array}{c}\text { 18. NUMBER } \\
\text { OF ABSTRACT }\end{array}$ \\
OF PAGES & \\
& 49 \\
\hline
\end{tabular}

19a. NAME OF RESPONSIBLE PERSON

19b. TELEPHONE NUMBER (include area code) 